\title{
STRATIGRAPHY OF THE GOIÁS AND FAINA GREENSTONE BELTS, CENTRAL BRAZIL: A NEW PROPOSAL
}

\author{
MARCELO GONÇALVES RESENDE*, HARDY JOST*, GRANT ALAN OSBORNE** AND AUGUSTO \\ GONÇALVES MOL**
}

\begin{abstract}
RESUMO ESTRATIGRAFIA DOS GREENSTONE BELTS DE GOIÁS E FAINA: UMA NOVA PROPOSTA A porção sul dos terrenos arqueanos de Goiás contém um greenstone belt estruturado em um sinclinório NW-SE, com $150 \mathrm{~km}$ de comprimento e $7 \mathrm{~km}$ de largura média e interpretado, no passado, como uma única faixa. Novos dados litológicos e estruturais mostram que a faixa é formada por dois segmentos alóctones (Goiás e Faina) com conteúdos estratigrá ficos distintos e justapostos por uma falha destral NE.

O contato dos complexos granito-gnáissicos com as rochas supracrustais é ora tectônico, ora intrusivo e a aloctonia dessas indica que os complexos não são rochas do embasamento original. As seções inferiores de ambas as faixas são idênticas (Grupo Santa Rita) e contêm, da base para o topo, metakomatiitos (Formação Manoel Leocádió) e metabasaltos (Formacão Digo-Digo). Na Faixa Goiás, a Formacão Digo-Digo é subdividida em um Membro Inferior (metabasaltos) e um Superior (rochas metapiroclásticas félsicas), esse último ausente em Faina. Os metabasaltos dão lugar, em ambas as faixas, a espessas sequências metassedimentares.

$\mathrm{O}$ registro metassedimentar da Faixa Goiás é representado pelo Grupo Fazenda Paraíso, subdividido, da base para 0 topo, nas Formaçóes Fazenda Limeira e Fazenda Cruzeiro. A primeira tem um Membro Inferior de xistos carbonosos e um Superior de metachert, formações ferríferas, calcixistos e mármores. A Formação Fazenda Cruzeiro consiste de metarritmitos siliciclásticos.

Em Faina, o registro mctassedimentar é representado pelo Grupo Furna Rica, subdividido, da base para o topo, nas Formações Fazenda Tanque, Serra de Sáo José e Córrego do Tatu. A Formação Fazenda Tanque repousa em discordância sobre metabasaltos do Grupo Serra de Santa Rita e contém um Membro Inferior de ortoquartzi tos e lentes de metaconglomerado com clastos de metavulcânicas máficas e ultramáficas, um Intermediário de metapelitos e um Superior de xistos carbonosos e formações ferríferas. A Formação Serra de São José repousa em discordância sobre a Formação Fazenda Tanque e contém um Membro Inferior de ortoquartzitos e um Superior de metapelitos com raros quartzitos. A Formação Córrego do Tatu contém um Membro Inferior de mármores e um Superior de formações ferríferas.

Os contrastes no registro sedimentar entre as faixas é interpretado como fruto de distintos ambientes paleogeográficos e regimes deposicionais. Em Goiás, a sedimentação ocorreu em ambiente marinho profundo e progrediu para ambiente mais raso, ao passo que em Faina a sedimentação foi plataformal em dois ciclos transgressivos de profundidade crescente. Dados gcoquímicos de rochas detríticas ao longo das seções estratigráficas mostram que a idade modelo $\mathrm{Sm} / \mathrm{Nd}$ (TDM) da área-fonte decresce de 3.1 a $2.8 \mathrm{Ga}$ e que a carga elástica dos protólitos derivou rochas máfico/ultramáficas, com aumento de uma componente félsica para o topo.

O núcleo do sinclinório da Faixa Goiás contém, ainda, uma estreita faixa de metaconglomcrados e ortoquartzitos (Sequência Serra do Cantagalo) de idade modelo Sm/Nd de $2.3 \mathrm{Ga}$. A sequência está invertida e sobrepõe-se ao greenstone belt por uma falha de empurrão e ambas delineiam o sinclinório regional, indicando que a estrutura não é de idade arqueana, mas no máximo paleoproterozóica.
\end{abstract}

Palavras-chave: Goiás, Greenstone Belts, estratigrafia, evolução de bacia

ABSTRACT The southem part of the Archaean terranes of the State of Goiás, Central Brazil, contains a NW-SE greenstone belt synclinorium, $150 \mathrm{~km}$ long and averaging $7 \mathrm{~km}$ wide, which was previously interpreted as one single belt. New lithological and structural data show that the belt consists of two allochthonous segments, the Goiás and Faina Greenstone Belts, with contrasting stratigraphic sequences juxtaposed by a NE-trending dextral fault. The contact bctween the graniloid complexes and the supracrustal sequences is either tectonic or intrusive, indicating that the complexes are not basement of the Greenstone Belts. The Goiás and Faina Greenstone Belts have common lower sections (Serra de Santa Rita Group), composed from base to top of metakomatiites (Manoel Leocádio Formation) and metabasalts (Digo-Digo Formation). In the Goiás Belt, the Digo-Digo Formation is subdivided into a Lower and an UpperMember, of metabasalts and felsic metapyroclastics respectively, the latter being absent in the Faina Belt. In both belts, metabasalts are succeeded by thick metasedimentary sequences.

The Fazenda Paraiso Group, subdivided into the lower Fazenda Limeira and the upper Fazenda Cruzeiro Formations, represents the metasedimentary record of the Goiás Greenstone Belt. The Fazenda Limeira Formation hás a Lower Memberof carbonaceous schist and an Upper Member of metachert, banded iron formation, calc-schist and marble. The Fazenda Cruzeiro Formation consists of siliciclastic metarhythmites.

The Furna Rica Group represents the metasedimentary record of the Faina Greenstone Belt, and is subdivided, from base to top, into the Fazenda Tanque, Serra de São José, and Córrego do Tatu Formations. The Fazenda Tanque Formation rests unconformable on metabasalts of the Serra de Santa Rita Group, and contains a Lower Member of orthoquartzites with lenses of metacpnglomerate, an Intermediate Member of metapelites, and an Upper Member of carbonaceous schists and iron formation. The Fazenda Tanque Formation contains a Lower Me mberof orthoquartzites with minor marble lenses, and an Upper Member of metapelites. The Córrego do Tatu Formation comprises a Lower Member of marbles and an Upper Member of banded iron formations.

The sedimentary contrast between the Greenstone Belts is interpreted as due to distinct paleogeographic settings and deppsitional environments. In the Goiás Belt, sedimentation took place in a deep, yet progressively shallower, marine environment, whilst in the Faina Belt the sedimentation took place in a shelf environment with two transgressive and progressively deeper marine cycles.

Geochemical data of clastic metasedimentary units show that the $\mathrm{Sm} / \mathrm{Nd}$ model age (TDM) decreases from 3.1 to 2.8 Ga across the sedimentary record, interpreted as the age range of the source-area, and that the clastic load may be explained by a major contribution from mafic/ultramafic rocks, with increasing felsic contribution towards the top of the sequences.

The core of the Goiás Greenstone Belt synclinorium also contains a narrow zone of metaconglomerates and orthoquartzites (Serra do Cantagalo Sequence) of $\mathrm{Sm} / \mathrm{Nd}$ model age of $2.3 \mathrm{Ga}$. This sequence is overturned and overlies the greenstone belt via a thrust fault. Both the Archaean and Protcrozoic rocks delineate the synclinorium of the Goiás Belt, indicating that the structure is not of Archaean, but, at most, of Palaeoproterozoic age.

Keywords: Goiás, Greenstone Belts, stratigraphy, basin evolution

* - Instituto de Geociências, Universidade de Brasília, 70919-970 - Brasília, DF, Brazil, e-mail: hjost@tba.com.br

** - Mineração Jenipapo S/A - Estrada da Barra da Tijuca, 1636, Bloco B, Loja A, 22641-001 - Rio de Janeiro, RJ 
INTRODUCTION The Greenstone Belts of Goiás and of Faina are constiluted of low grade metamorphic supracrustal rocks and are located in the southern part of the Archaean terranes of the State of Goiás, Central Brazil (Fig. 1). Togelher, the belts are approximately $150 \mathrm{~km}$ long and average $7 \mathrm{~km}$ wide, being confined bclween the Itapuranga and Uva granitoid Complexes (Jost et al. 1998). The belts trend N50'$70^{\circ} \mathrm{W}$ and $\mathrm{N} 30^{\circ}-50^{\circ} \mathrm{W}$, respectively. They are both synclinoria (Fig. 2) separated by the NE-trending, dextral Faina Fault in the proximity of the town of Buenolândia.

The gross stratigraphic sequences of both belts comprise lower metavolcanic rocks beginning with metakomaliites and culminating with metabasalts, locally felsic metavolcanics, followed by upper metasedimentary rock packages. Since the early 1980's, when Danni et al. (1981) First interpreted these supracrustal rocks as typical Greenstone Belts, their metallogenetic potential stimulated the detailed study of the metavolcanics, in detriment of the metasedimentary sequences.

Jost \& Oliveira (1991) first noted that the three greenstone belts of the northern part of the Archaean terranes of the State of Goiás (i.e., Crixás, Guarinos, and Pilar de Goiás, Fig. 1) have similar metavolcanic packages but differ in the upper metasedimentary sequences, probably as a result of distinct paleogeographic settings. To enhance the differences and facilitate a better understanding of the sedimentary evolution, the authors proposed individual stratigraphic models for each belt. Further detailed observations by Jost et al. (1989), Resende (1994), Resende and Jost (1994), Theodoro (1995), Resende (1995), Jost et al. (1995), Jost et al. (1996a, 1996b), and Lacerda and Lima Jr. (1996) led to the conclusion that the sedimentary stratigraphy of those belts could not adequately be resolved only by documenting rock types. Additional sedimentological, geochemical, isotopic, and structural data became, in many cases, more important then rock classification.

The progress in the last two years of the understanding about the sedimentary stratigraphy and evolution of the three Greenstone Belts of the northern portion of the Archaean terranes motivated the application of the experience acquired there in detailing the Goiás and Faina belts, situated in the southern portion. This would lead to a complete picture of the variety of sedimentary records preserved in the five Greenstone Belts of the State of Goiás. Geological mapping at 1:25.000 scale allowed to detail the compositional, textural, and structural field characteristics of the metasedimentary units of both belts, further complemented by petrographic, geochemical, and isotopic data of the fundamental lithologies (Resende and Jost 1997). The isotopic data reveal that the Goiás and Faina belts are coe vai, but they have contrasting sedimentary successions that make correlation on a lithologic basis impossible. Hence, the understanding of their respective sedimentary histories is better described by means of individual stratigraphic models. As a result, the aims of this paper are to formally propose a new stratigraphy for each belt, interpret their respective sedimentary histories, and define the role played by the Faina Fault, that separates these contrasting palaeogeographic settings.

Ali the original supracrustal rocks of the studied belts underwent greenschist fácies metamorphism and several deformational episodes. The most prominent structural features derive from thrusting during the Archaean and the Proterozoic. Therefore, the authors are aware that the stratigraphic models here proposed are based on sequences that have been preserved after the Neoproterozoic Brasiliano Cycle, and that some of the original rock types may have been suppressed by deformation during the Pre-Cambrian. On the other hand, monitoring of the effects of structural features on the preserved stratigraphy shows that repetition, suppression, thickening, thinning, and lens-shaping of rock-types and strati-

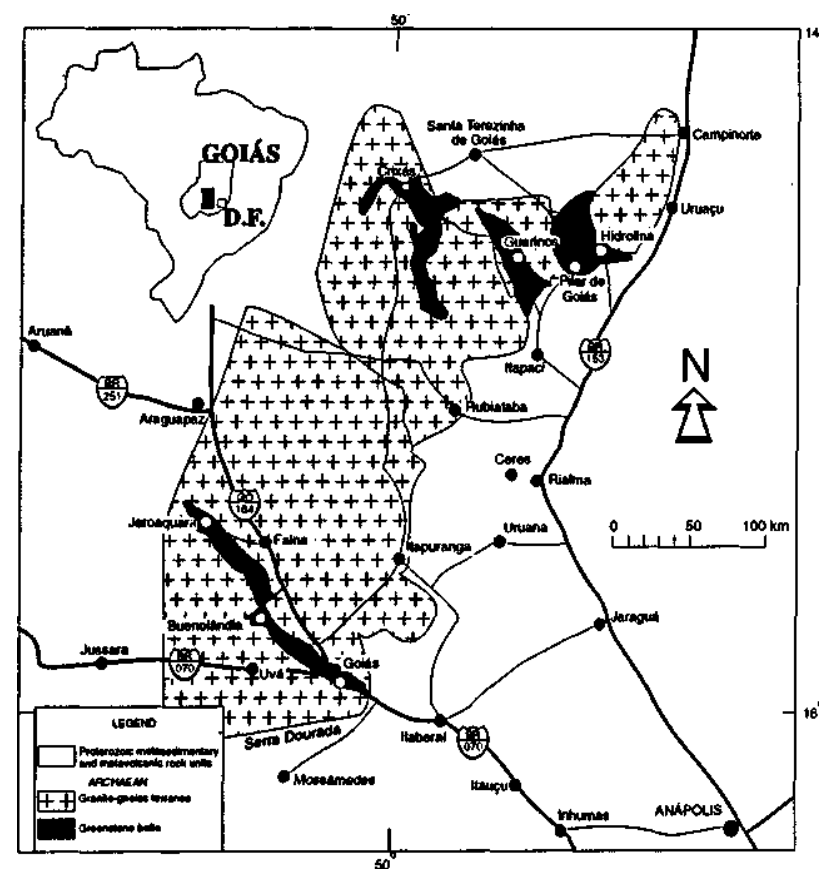

Figure 1-Geographic location and geology setting of the Goiás and Faina Greenstone Belts Central Brazil.

Figura 1 - Localização geográ fica e situação geoló gica dos Greenstone Belts de Goiás e Faina.

graphic units are probably due more to tectonic processes than primary features. Although primary contact relationships between the proposed units are preserved in many outcrops, the stratigraphic models have, thus, more a tectono-stratigraphic than a lithostratigraphic sense.

\section{PREVIOUS STRATIGRAPHIC NOMENCLATURES}

Danni et al. (1981) proposed the first stratigraphic subdivision of the Goiás Greenstone Belt. These authors interpreted the supracrustals of this belt as consisting of two metamorphic sequences. The oldest, considered to be Archaean, was named the Serra de Santa Rita Sequence and was subdivided into three Units. The Lower Unit was described to consist of ultramafic metavolcanics, the Intermediate of mafic metavolcanics, and the Upper of metasedimentary rocks. The younger was named the Serra do Cantagalo Sequence, represented by metaconglomerates and conglomeratic quartzites overlain by metadolomites and itabirites, and was interpreted as representing a Proterozoic shelf deposit similar to, and correlated with, units of the Quadrilátero Ferrífero (Minas Gerais) and the Serra da Jacobina (Bahia). The presence of metaconglomerates with fragments of mafic supracrustals supported the conclusion that the source área would be the underlying Greenstone Belt and, therefore, that the Serra do Cantagalo Sequence would rest on an erosional unconformity.

In the same year, Teixeira (1981) formally proposed to group the Goiás Belt supracrustals under the Goiás Velho Group, informally subdivided into three units. The Basal Unit consisted of ultramafic metavolcanics, the Intermediate Unit of mafic and felsic metavolcanics, and the Upper Unit of metasedimentary rocks including the Serra do Cantagalo Sequence of Danni et al (1981). The author suggested that the supracrustals might be divided into the Goiás and Faina Blocks, separated by a strike-slip fault, and with rock associations differing in some aspects. The Goiás Block would contain thicker ultramafic and mafic metavolcanic sequences whilst the metasedimentary rocks would be predominantly 


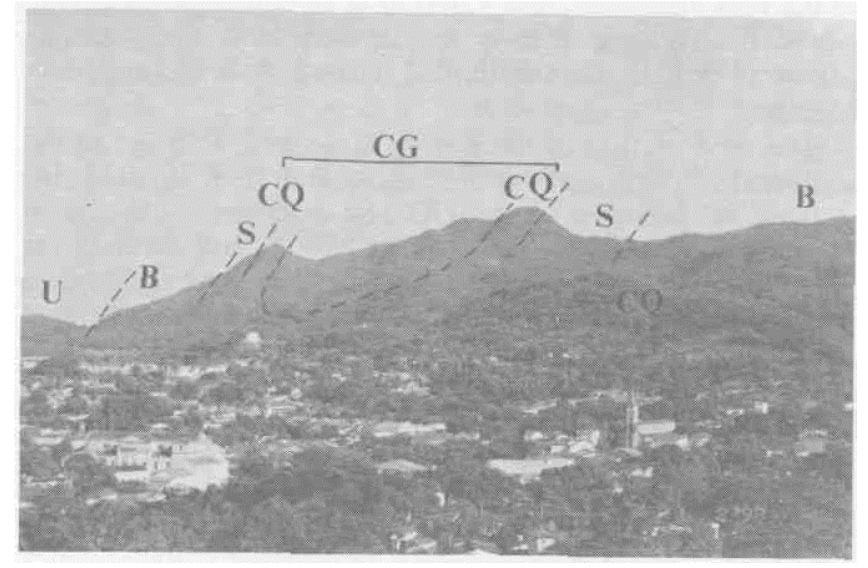

Figure 2 - Panoramic view of the core of the Goiás Greenstone Belt synclinorium, with the town of Goiás in the foreground. The inverted limb ofthe fold is to the left. Archaean units: $U$ $=$ metakomatiites, $B=$ metabasalts, and $S=$ metasedimentary rocks. Proterozoic units: $C G=$ Serra do Cantagalo Seqnence, $C Q=$ crest ofquartzites and metaconglomerates ofthe Serra do Cantagalo Seqnence docitmented in Figure Wandsitaated in the inverse limb ofthe structure.

Figura 2 - Vista panorâmica do núcleo do sinclinóiio do Greenstone Belt de Goiás, com a cidade de Goiás em primeiro plano. O flanco inverso é o da esquerda. Unidades arqueanas: $\mathrm{U}=$ metakomatiitos, $\mathrm{B}=$ metabasaltos e $\mathrm{S}=$ rochas metassedimentares. Unidades do Proterozóico: $\mathrm{CG}=$ Sequência Serra do Cantagalo, $\mathrm{CQ}=$ crista de quartzitos e metaconglomcrados da Sequência Serra do Cantagalo documentados na figura 10 e situados no flanco inverso da estrutural.

graphite schists, quartzites, and intraformational metaconglomerates. The Faina Block would be represcnted by a thicker metasedimcntary sequence, dominated by muscovitechlorite-quartz schist and dolomitic marbles.

Later, Tomazzoli (1985) and Tomazzoli \& Nilson (1986) subdivided the Goiás Velho Group, in the Goiás Belt, in thrce units. The Basal, or Lower Ultramafic Unit containing ultramafic rocks, locally massive and with relict spinifex lexture, and intercalations of iron-rich mctachcrt, graphitic phyllite and metapelitc. The Intermediate, or Basic Unit was described as consisting of mafic metavolcanics and fclsic metatuffs with intercalations of mctachert, graphitic phyllitc, and metapelite. The Upper, or Metasedimentary Unit would comprise metapelites, locally graphitic, wilh minor mctachcrt, banded iron formations, and hemalite-dolomitc marblc. The authors included the Serra do Cantagalo Sequence in the Upper Unit, subdividing it into a Lower sub-unit of metaconglomerates, orthoquartzites, and metapelites, and an Upper sub-unit of feldspathic graded metagreywackes with rhythmic intercalations of metapelite and quartzite.

The first $1: 50,000$-scale, geological mapping of the Faina Block was performed during 1988, by students ofthe Geology Course of the University of Brasília, lead by Professors Ariplínio António Nilson, César Fonseca Ferreira Filho and Almir Neves Figueiredo. In the unpublished reporls of Rosa and Machado Filho (1988), Rodrigues and Santos Neto (1988), Vieira and Duarte (1988), Oliveira and Barreto (1988), Castro Júnior and Talhari Júnior (1988), Scartczini and Carvalho (1988), and Costa and Castro (1988), the supracrustal rocks of Faina were grouped into the Goiás Velho Group and subdivided into three Units. The Basal, or Volcanic Unit is described as being made up of ultramafic and mafic metavolcanics locally with metapelite. The Intermediate, Psammo-Pelitic Unit would consist of micaschist and quarlz- schists with minor quartzite, Mg-rich schist, and lenses of banded iron formation and dolomite, whilst the Upper, Chemical Sedimentaiy Unit, of marbles and banded iron formation ofthe oxide, and locally sulfide, fácies.

Conscquently, whilst the Greenstone Belt of Goiás was blesscd with an initial informal published stratigraphic schcme that progressed inlo a semi-formal model, the semiformal stratigraphy ofthc Faina Belt hás never been disclosed. In this new proposal, we substitute the informal and semi-formal by a formal stratigraphic nomcnclature, and then for each bclt we proposc a separatc stratigraphic model. Teixcira's (1981) tcrm Goiás Velho Group is not maintained because there is no such locality in the region, being merely a colloquial term. The new proposed stratigraphic nomenclatures are summarized in Figure 3. Considering that both belts have similar lowcr metavolcanic sequences but differ in their metascdimentary assemblage, the following paragraphs describe the volcanic units under one singlc title, followed by the separatc description of the mctassedimentary units of each bclt.

On the other hand, it is worlh to comment that the tovvn of Faina is locatcd on granitoid rocks of the Itapuranga Complex (Figs. 1 and 4), approximately $15 \mathrm{~km}$ to lhe north ofthe Faina Bclt. Historically the bclt hás bcen known by this designation and wc optcd to continue to use it as the closest important gcographical rcfcrence.

\section{METAVOLCANIC ROCKS OF THE GOIÁS AND} FAINA GREENSTONE BELTS: THE SERRA DE SANTA RITA GROUP Metakomatiites and metabasalts make indistinctly up the lowcr stratigraphic sequence of the Goiás and Faina belts. The equivalem ultramafic and mafic metavolcanics can be traced from the Goiás Belt northwards until they abut with similar rocks in the Faina Belt on the oppositc sidc of the Faina Fault. It is thercfore pointless to create new names for the lower metavolcanic units to each bclt. We, thereforc, propose to group these rocks under one single stratigraphic unit, by raising the former Serra de Santa Rita Sequence of Danni et al. (1981) to the formal category of Group. The name derives from the mountain range sustained by the Faina Greenstone Belt near lhe town of Jcroaquara. The Serra de Santa Rita Group is subdivided inlo lhe Manoel Leocádio and Digo-Digo Formalions. The regional dislribulion of lhese units in bolh bells is shown in figures $4 \mathrm{a}$ and $4 \mathrm{~b}$, respeclivcly.

Manoel Leocádio Formation The lype-section ofthe Manoel Leocádio Formalion lies along lhe Córrego Manoel Leocádio, which flows over rocks of this unit in the Goiás Belt, culting lhe GO-164 road approximalely $6 \mathrm{~km}$ north of the town of Goiás (Fig. 4a). In the Goiás Bclt, the formalion is 50 to $1,000 \mathrm{~m}$ Ihick, in average $600 \mathrm{~m}$, decreasing in lhe Faina Bclt to betwecn 200 and $400 \mathrm{~m}$, in the average of 300 $\mathrm{m}$. The unil consists of ultramafic rocks largely transformed into serpenlinite, and to a variety of schists with variable amounts of tale, carbonate, chlorite, and Iremolite. Carbonaceous schist or puré to hematile-bearing melacherl occur as local mctric inlcrcalations in the ultramafics.

The ultramafic rocks locally display primary structures, such as pillows (Danni et al. 1981), polyhedral joinling (Teixeira 1981), and relíeis of spinifex and cumulale textures (Tomazzoli 1985, Profumo 1993). These struclural and lextural rclicts, as well as the intcrcalalions of rocks derived from chemical protoliths and peliles rich in organic malter indicale that the majority of ullramafic rocks derive from komaliiles. For Profumo (1993), lhe inlense deformalion shown by mosl of the komaliiles inhibils accurale eslimales of the original ihicknesses of individual flows, bui lhey probably vary beIween $2 \mathrm{~m}$ and $30 \mathrm{~m}$. 
The formation constitutes the externai fringe of lhe Goiás and Faina Greenstone Belts (Figs. 4a and 4b), and is in contact with granite-gneiss terranes of the Itapuranga and Uva Complexes either via a faulted or intrusive contact. The faults are marked by WNW-trending mylonite zones. In the Goiás Belt, the mylonites have an average dip of $50^{\circ} \mathrm{SW}$, while in lhe Faina Belt they rarely dip more than $20^{\circ} \mathrm{SW}$. Kinematic indicators show that the faults have a NE-vergence and suggest that the supracrustal sequence is allochthonous. Howevcr, parts of the complexes are granitoid inlrusions, as indicalcd by lhe abundance of supracruslal xenolilhs in granile and granodiorile bodies (Fig. 5). These fealures indicale lhal lhe Itapuranga and Uva Complexes cannot be interpreled as the original basement of the volcano-sedimenlary sequence.

Digo-Digo Formation In the Goiás Belt; the Digo-Digo Formation is between $200 \mathrm{~m}$ and 1,000 m ihick, decreasing lo $100 \mathrm{~m}$ Io $500 \mathrm{~m}$ ihick in lhe Faina Belt. The unit is divided inlo a Lower and an Upper Member.

The lype-seclion of the Lower Member is localed along the Córrego Digo-Digo, east of the lown of Goiás (Fig. 4a). Il consisls of mafic volcanic rocks Iransformed inlo amphibolc schists with variable proporlions of aclinolite, albile, epidole and quarlz, wilh intercalations of Ihin layers of feldspalhic melaluff, tale schist, carbonaceous melapelile and metacherl. The melabasalts of both bclts are very similar, but il is noleworthy thal lhese rocks are, in general, much more altercd (carbonalization + sericitizalion) in lhe Faina lhen lheir equivalents of lhe Goiás Belt.

The type-seclion of lhe Upper Member is locatcd ncar the confluence of the Digo-Digo Creek wilh lhe Vermelho River (Fig. 4a). The unil consisls of sericile-chlorile-quarlz schisls wilh relíeis of original pyroclaslic textures varying from recryslallized ash to coarse tuffs, including abundam layers with lapilli-size fragments (Fig. 6). The composilion of lhe felsic luffs varies from dominanlly dacitic lo minor rhyolilic. The melaluffs conlain meler ihick layers of melachert, carbonaceous schist, and tale schist. The diagnostic pyroclastics of the Upper Member have só far been found only in the Goiás Belt. In spite of bcing absent in the Faina Bell, il is possible lhal isolated melric lo decametric subvolcanic felsic sills occurring adjacent and lo the north of the Faina Fault may be correlated wilh the felsic volcanics of the Goiás Belt.

The contact belween the metabasallsof the Lower Member and the underlying metakomatiites of lhe Manoel Leocádio Formalion is gradalional in bolh belts, although leclonic conlacls are more common. This transilion occurs Ihrough the gradual increase of basallic layers wilhin the melakomaliites. As noled by Tomazzoli (1985) in lhe Goiás Belt, lhe contacl belween the melabasalls of lhe Lower Member and lhe felsic pyroclaslics of the Upper Member is also gradational, and given by an approximalely $100 \mathrm{~m}$ ihick section with intercalalions of lilholypes of bolh unils.

METASSEDIMENTARY STRATIGRAPHY OF THE GOIÁS GREENSTONE BELT The lypical, Archaean, melasedimentary rocks of the Goiás Belt comprise the Fazenda Paraíso Group. The group is parlially overlain by lhe Serra do Canlagalo Sequence, probably of the Palaeoproterozoic, along a folded thrust fault. The dislribulion of lhese unils is shown in Figure $4 \mathrm{a}$.

Fazenda Paraíso Group The Fazenda Paraíso Group is entirely metasedimentary. The unit is subdivided, from base to top, into the Fazenda Limeira and Fazenda Cruzeiro Formalions (Fig. 3).

FAZENDA LIMEIRA FORMATION The type-section of the Fazenda Limeira Formalion is localed near the Limeira Farm, approximately $3.5 \mathrm{~km}$ norlheasl of the town of Goiás (Fig. 4a).
Its oulcrop Ihickness varies belween $300 \mathrm{~m}$, in the proximity of the Rio Vermelho, and 1,000 $\mathrm{m}$ at ils soulheaslern extenl, where lhe leclonic effecls are less evidenl. The Fazenda Limeira Formalion is subdivided inlo a Lower and an Upper Member.

The lype seclion of the Lower Member is situated in the southeaslern porlion of the Greenstone Belt (Fig. 4a). Il begins ai lhe road junclion of the GO-164 highway with a local unpaved road to the Córrego Digo-Digo, and extends for approximalely $1,000 \mathrm{~m}$ along ihis road. The seclion consists of carbonaceous schist wilh local, melric layers of melapelite and melacherl. The conlacl wilh the mafic metavolcanic rocks of the Serra de Sanla Rita Group is either transitional, given by the alternation of the diagnoslic lilholypes of both units, or leclonic by way of a west-north-west striking thrust fault.

The Upper Member occurs along the whole northern normal limb of the synclinorium of the Goiás Bell. To lhe norlhwesl, lhe conlacl is lectonic with the basic metavolcanics of lhe Digo-Digo Formalion, whilsl lo lhe soulheasl, the conlacl wilh the carbonaceous schists of the Lower Member is transitional. The unil is approximalely $100 \mathrm{~m}$ thick and consists of a basal metacherl that grades into an iron-rich mctachcrt and an oxide fácies banded iron formation. The iron formation gives way to approximately $50 \mathrm{~m}$ of massive, white to gray, calcile-dolomile marble (Fig. 7), eilher directly, or through approximalely $10 \mathrm{~m}$ of carbonale-bearing sericitequartz schist.

FAZENDA CRUZEIRO FORMATION Near the town of Buenolândia, the Fazenda Cruzeiro Formation occurs in both limbs of the Goiás Bell synclinorium, whilsl near lhe town of Goiás it is restricted lo lhe inverted limb of the structure (Fig. 4a). The formalion hás an oulcrop Ihickness of approximately $500 \mathrm{~m}$ and is divided inlo a Lower and an Upper Member.

The lype-seclion of lhe Lower Member is localed $2 \mathrm{~km}$ south of Buenolândia (Fig. 4a) along lhe unpaved road from ihis lown lo the Goiás-Uvá Highway (BR-070). Il consisls of mclarhylhmiles (Fig. 8a) composed of decimelric layers of feldspalhic or mica-bearing quartzile grading inlo layers of melapelile. The melarhylhmiles are, in general, organized in cycles. Each cycle begins wilh meler ihick lhal gives place, lowards lhe lop, lo cenlimelric rhythms, indicating that the beginning of cach cycle took place under higher energy leveis than at ils end.

In lhe lype seclion, lhe melarhylhmiles c'rop oul in both limbs of the regional synclinorium. On lhe western limb, the bedding strikes norlhwest and dips to southwesl, and the younging direction given by graded bedding is lowards struclurally lower strata, indicaling an inverse limb of lhe synclinorium. In lhe symmelrical easlem limb, lhe slrala also strike northwesl and dip lo soulhwesl bui lhe younging direclion is lowards slruclurally higher leveis indicating a normal limb.

The lype seclion and besl exposures of lhe Upper Member are located immediately lo lhe south of Zanzã Farm (Fig. 4a). The member also occurs at the top of lhe lype-seclion of lhe Lower Member, bui il is nol well exposed due to weathering. The Upper Member consisls of a succession of cenlimelric layers of feldspalhic and micaceous, fine lo médium, gray quarlzile wilh relict primary sedimentary fealures, such as cross-bedding and cut-and-fill struclures (Fig. 8b). Cenlimetric layers of metapelile occur locally.

The contact between the Fazenda Limeira and Fazenda Cruzeiro Formations is rarely visible due lo the preferred occurrence of the former in the western and lhe latter in the eastern limb of lhe synclinorium. However, soulh of lhe Zanzã Farm, quarlzites of the Upper Member of the Fazenda Cruzeiro Formalion sharply overlie melacherls of the Limeira Formation. In general, lhe rocks of lhe Fazenda Cruzeiro Formation are in teclonic conlacl with rocks of the lower 


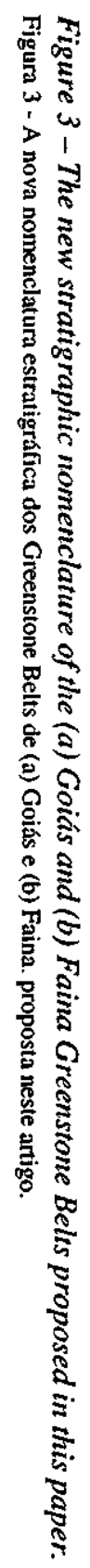
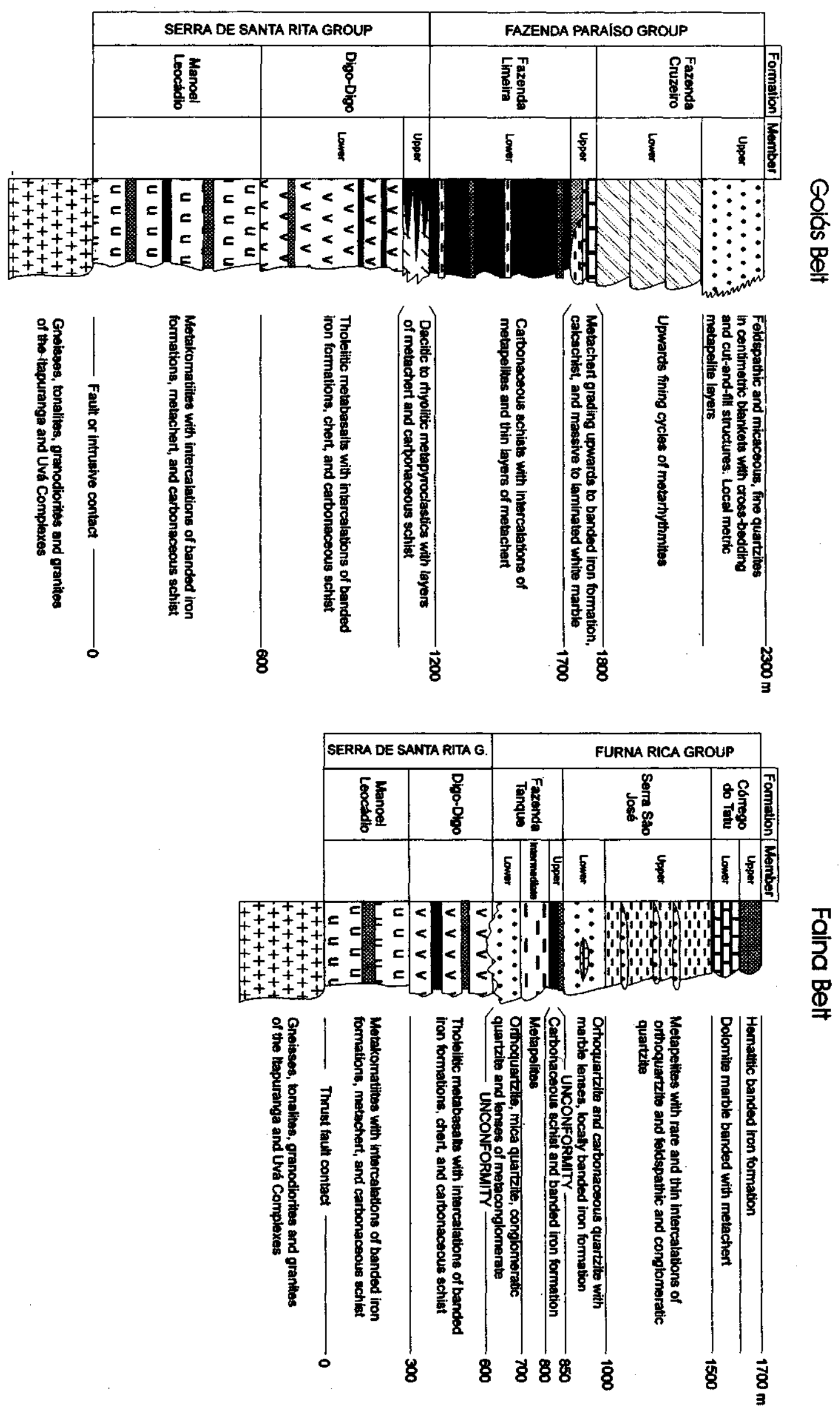


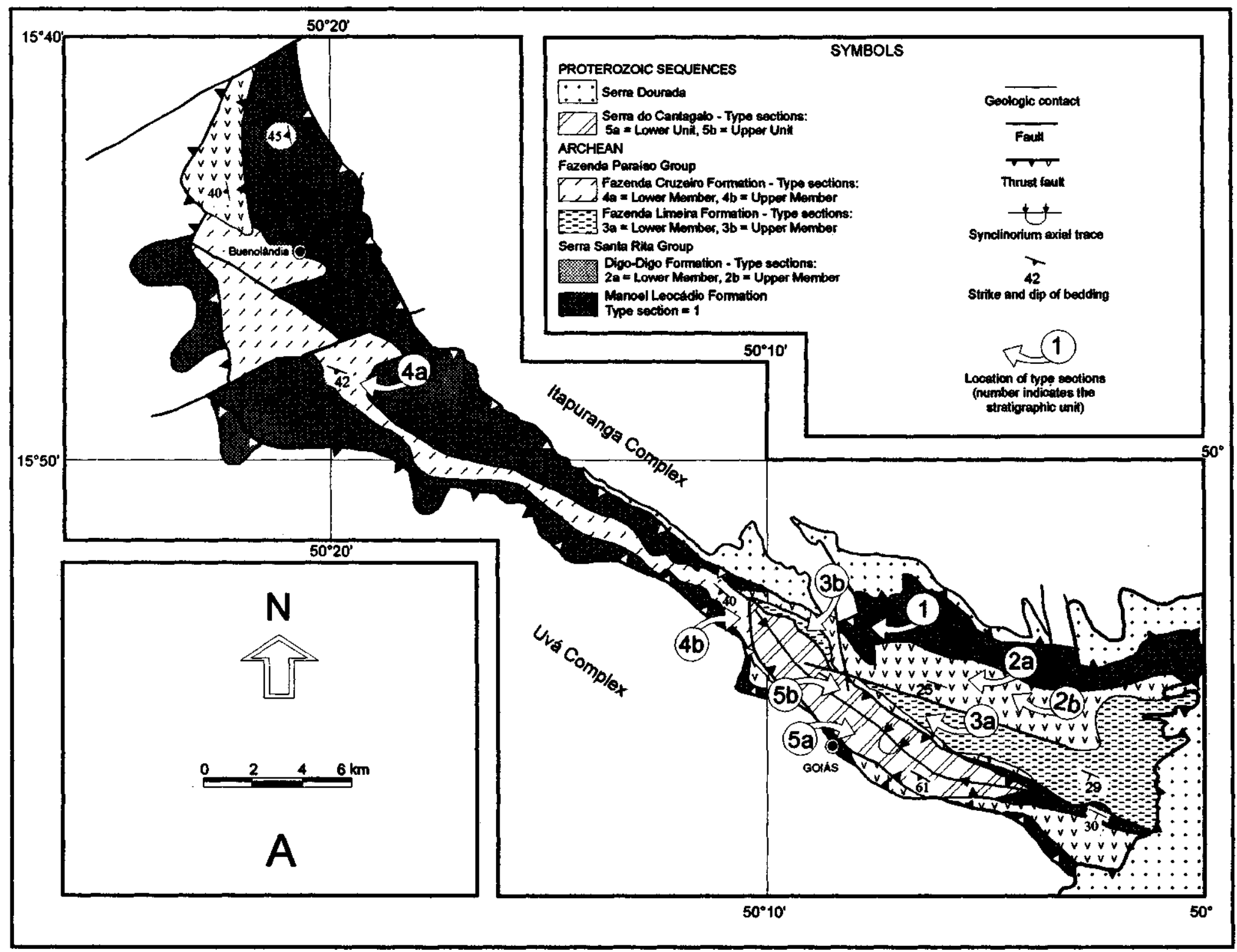

Figure 4A - Geological maps ofthe (A) Goiás and (B) Faina Greenstone Belts showing the distribution oftlie stratigraphic iinits ofthe Goiás and Faina Greenstone Belts. Owing to the scale ofthe maps, the locations ofthe type-sections is only approximate, bui are described in the text and their exact geographic situation may be determined with reference to the 1:100,000 scale topographic map ofBrazilian Institute ofGeography and Statistics (IBGE), sheet SD-22-ZC.

Figura 4 - Mapas geológicos dos Greenstone Belts de (A) Goiás e (B) Faina mostrando a distribuição das novas unidades estratigráflcas dos greenstone belts de Goiás e Faina. Por razões de escala, a localização das seçoes-tipo é aproximada, mas está descrita ao longo do texto e sua exata situação geográfica pode ser definida com o auxílio da carta topográfica do IBGE em escala 1:100.000, Folha SD-22-ZC. 


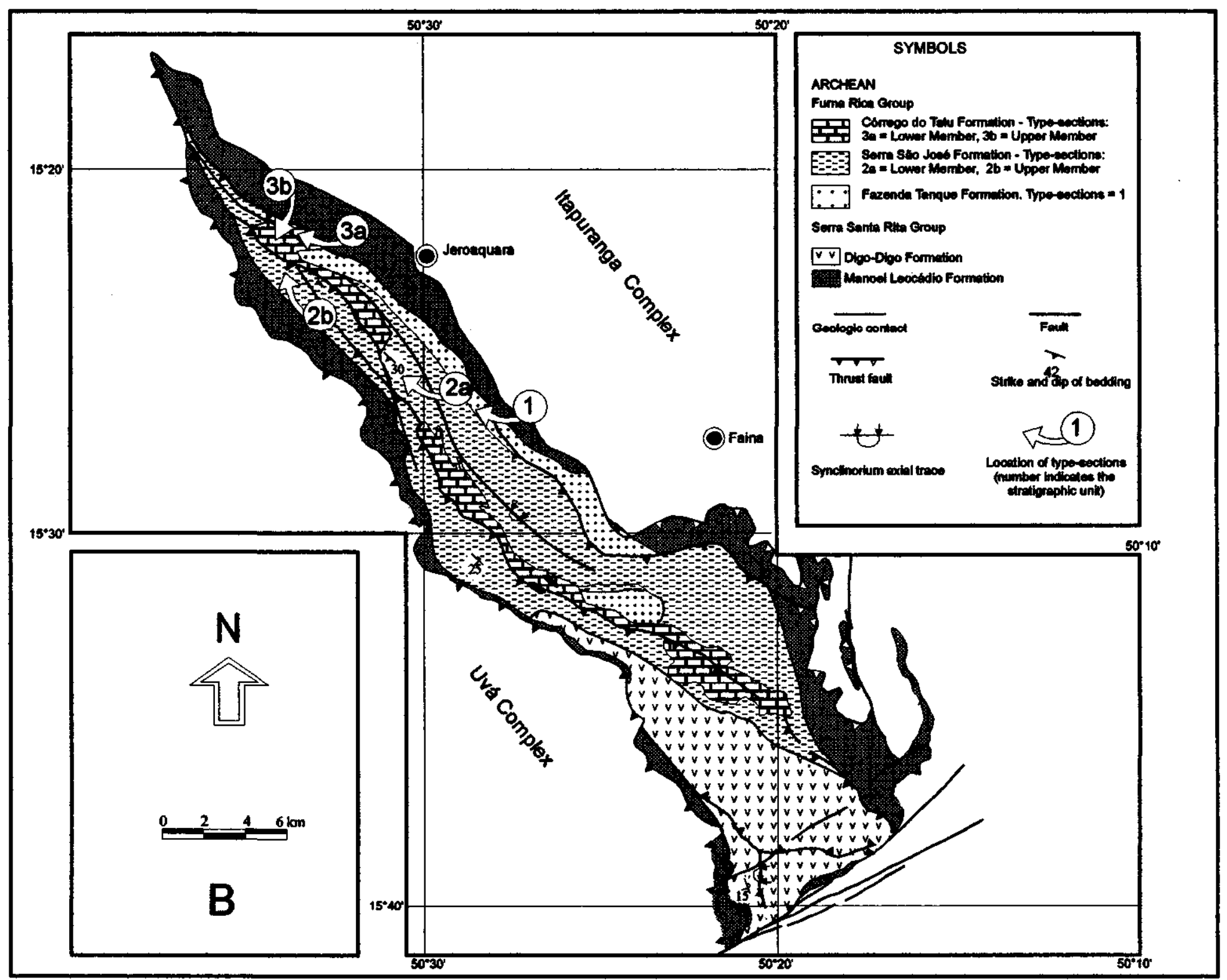

Figure 4B - Geological maps ofthe (A) Goiás and (B) Faina Greenstone Belts showing the distribution ofthe stratigraphic units of the Goiás and Faina Greenstone Belts. Owing to the scale ofthe maps, the locations ofthe type-sections is only approximate, but are described in the text and their exact geographic situation may be determined with reference to the 1: 100,000 scale topographic map of Brazilian Institute of Geography and Statistics (IBGE), sheet SD-22-ZC.

Figura 4 - Mapas geológicos dos Greenstone Belts de (A) Goiás e (B) Faina mostrando a distribuição das novas unidades estratigráficas dos greenstone belts de Goiás e Faina. Por razões de escala, a localização das seções-tipo é aproximada, mas está descrita ao longo do texto e sua exata situação geográfica pode ser definida com o auxilio da carta topográfica do IBGE em escala 1: 100.000, Folha SD-22-ZC. 


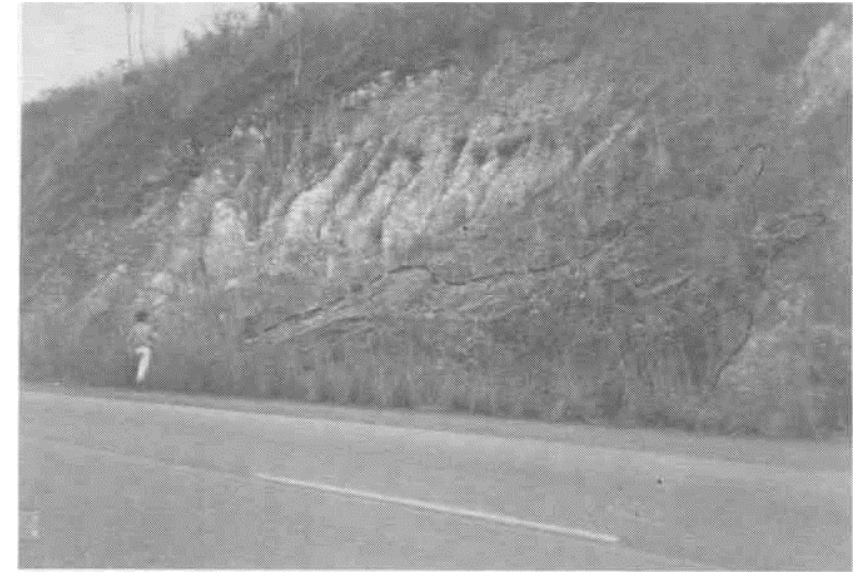

Figure 5 - Outcrop of the Itcipumnga Complex located approximately $10 \mathrm{~km}$ from the town of Goiás, on the road to Faina exposing a kaolinized granodiorite with xenoliths of ultramafic supracrustals.

Figura 5 - Afloramento do Complexo Itapuranga situado a cerca de $10 \mathrm{~km}$ da cidade de Goiás, na rodovia para Faina, expondo granodiorilo caulinizado com xenólitos de supracrustais ultramáficas.

stratigraphic units, and locally also with basic mctavolcanic rocks of the Serra de Santa Rita Group, as is the case at the type section of the Uppcr Membcr.

SERRA DO CANTAGALO SEQUENCE In this pró posai, we maintain lhe term Serra do Cantagalo Sequencc as originally proposed by Danni et al. (1981), for several reasons. First, the rocks of this scquencc and those of the Goiás Greenstone Belt were foldcd togclher into the regional synclinorium. Second, it occurs only in the axial zone of the Goiás Belt synclinorium, being absent in lhe Faina Belt. Third, no rocks that are similar to lhose of the sequence have só far bcen found in the neighborhood of bolh bells. Fourlh, because lhe ongoing debale as Io whelher lhe conlacl relationships of this sequence with lhe underlying Greenslone Bell is by means of an unconformily (Danni et al. 1981), or a natural, conformable succession (Teixeira 1981, Tomazzoli 1985), can be better defined on the basis of new slruclural and isolopic data.

The área of occurrence of Ihis sequence is illustrated in figure 4a. The unit is subdivided inlo a Lower Unil lhal grades inlo an Upper Unil.

The lype seclion of the Lower Unit is localed aboul $3 \mathrm{~km}$ norlh of lhe lown of Goiás (Fig. 4a). The unil is approximatcly $400 \mathrm{~m}$ thick and consisls of lowcr orlhoquartzilcs lhal grade upwards inlo sericile-quarlz schisls, and, in lurn, inlo quarlzmuscovile schisls. The quarlziles are while, fine, in general massive, bui may have rare primary slruclures such as planeparallel and cross bedding. The schisls are also white and fine, becoming coarser and more quarlz-rich towards the top of the unit.

The Upper Unit occurs only in the neighborhood of the town of Goiás and ils lype-seclion and besl exposure is localed in lhe Rio Vermelho, ai a local leisure spot named Largo da Carioquinha (Fig. 4a). The Unit starls wilh a Ihick succession of quarlziles, locally wilh granules of quarlz, giving place, lowards the top, Io conglomeratic quartziles with lenses of polymictic melaconglomerale. The quarlziles are fine, while, in general massive and lacking primary slruclures. The conglomeralic quarlziles are also while, bui are coarser lhan the quarlziles and carry while quarlz foi/nded granules. The melaconglomerales are clasl-supporled (Fig. 9a) and conlain pebbles of quarlz, melacherl, and locally chlorile-schisl, im-

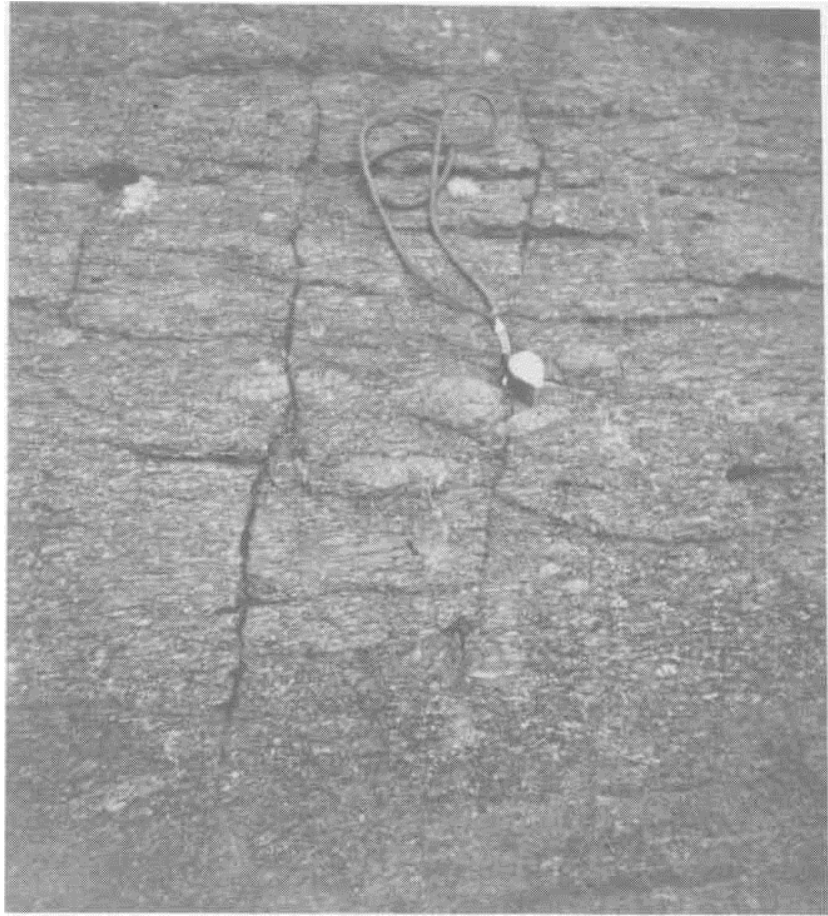

Figure 6 - Lapilli tuffofthe Upper Member ofilie Digo-Digo Fonnation.

Figura 6 - Lapili-tufo do Membro Superior da Formação Digo-Digo.

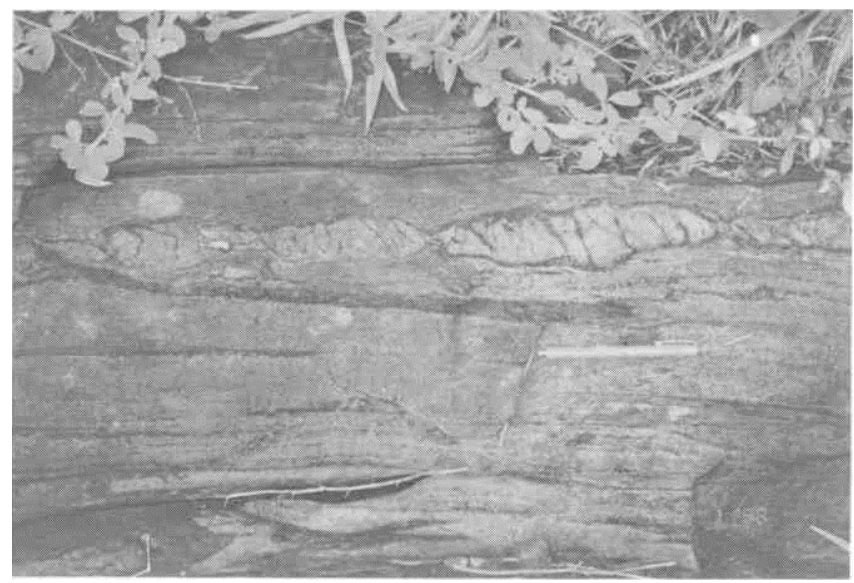

Figure 7- Outcrop ofa typical marble with en echelon boudins of the Upper Member of the Fazenda Limeira Fonnation, located approximately $500 \mathrm{~m}$ southwest ofthe Limeira Farm. Figura 7 - Afloramento de mármore com boudins en echellon, típico do Membro Superior da Formação Fazenda Limeira, localizada a cerca de 500 $\mathrm{m}$ a SW da Fazenda Limeira.

mersed in a chlorile-quarlz malrix wilh pyrile. The clasts are in general slrelched and form a conspicuous linealion plunging $60^{\circ}$ lo $70^{\circ}$ ai $S 30^{\circ}-40^{\circ} \mathrm{W}$. Bolh the conglomeralic quartzites and the metaconglomerales have abundam primary slructures such as planar-parallel bedding, cross-bedding and cul-andfill slruclures (Figs. 9b and 9c). 

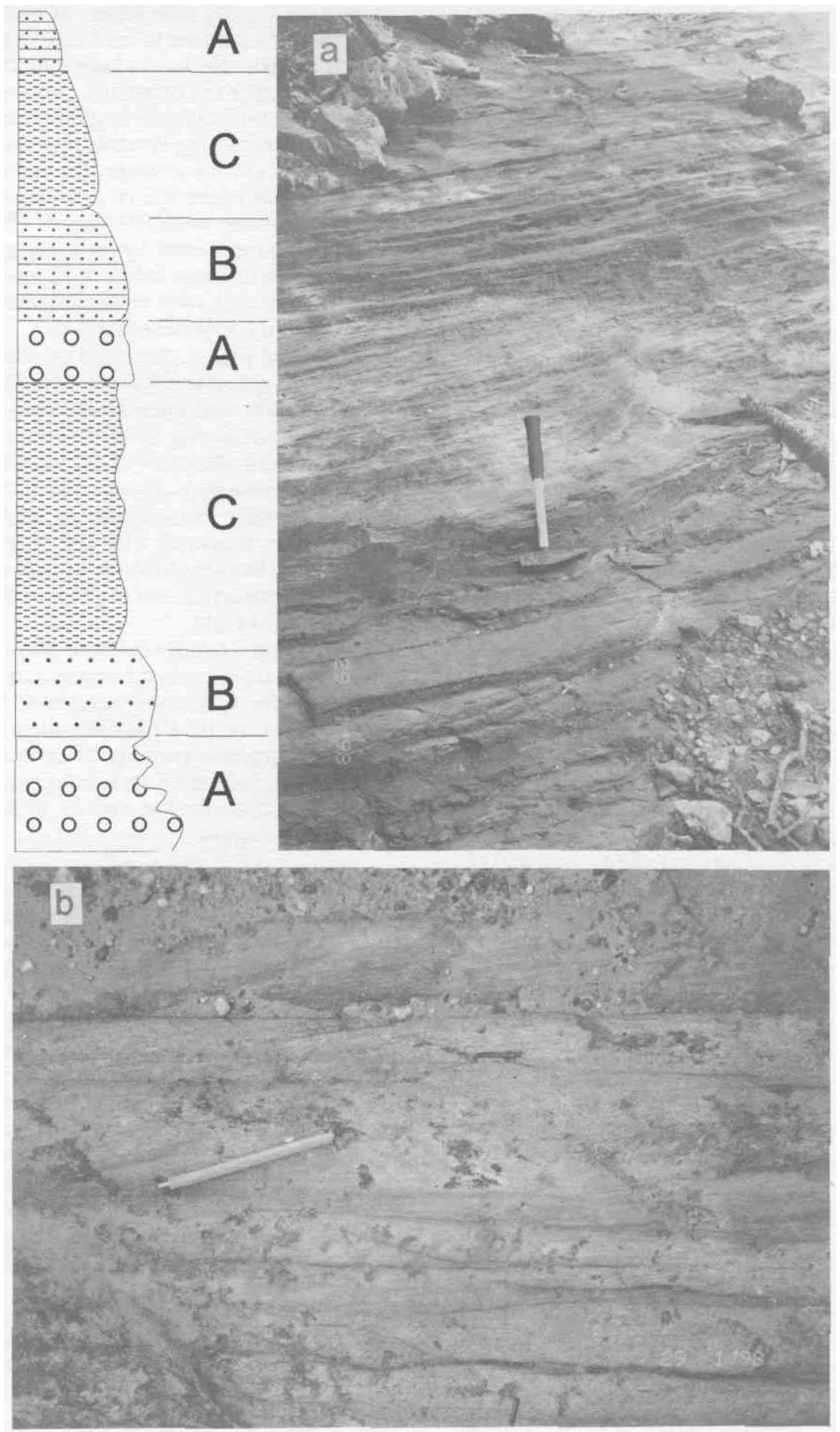

Figure 8-(a) - Outcrop of metarhythmite in the type section of the Lower Member ofthe Fazenda Cruzeiro Formation. A, B, and $C$ are coarse qitartzite, fme micaceous quartzite, and metapelite, respecüvely. (b) - Outcrop in the type-section of the Upper Member of the Fazenda Cruzeiro Formation showing several feldspathic quartzites with cross-bedding and cut-and-fill structiires. Figura 8 - (a) - Afloramento de metaritmito na seção-tipo do Membro Inferior da Formação Fazenda Cruzeiro. A, B e C são respectivamente, quartrzito grosso, quartzito fino micáceo e metapelito. (b) - Anoramcnto do Membro Superior da Formação Fazenda Cruzeiro na seção-tipo, mostrando diversos níveis de quartzitos feldspáticos com estratificação cruzada e de corte-e-preenchimento.

Detailed structural analysis ofthe Largo da Carioca outcrop showed that it occurs in inverse limb of the synclinorium (Fig. 2 ), as indicated by the rock sequence in the Greenstone Belt. The primary structures of metaconglomerates and conglomeratic quartzites of the Serra do Cantagalo Sequence at this outcrop indicate a younging direction toward structurally higher strata, and opposite to the younging directions given by the grccnstone sequence in the same limb. This can only be explained by means of thrusting and overturning of the Serra do Cantagalo Sequence before the folding of both together into the actual synclinorium.

This implies that the contact between the Archaean supracrustal rocks and the Serra do Cantagalo Sequence it is neither an erosive unconformity, as interpreted by Danni et al. 
(1981), nor is there a depositional continuity betwecn them as proposed by Teixeira (1981) and Tomazzoli (1985). The contact must be a foldcd thrust fault. Consequently, this also implies that the synclinorium is not of Archaean age, but formed after the tectonic transport of the Serra do Cantagalo Sequence into the área.

Several types of evidence of the existence of this contact fault occur in the área, and the most outstanding feature is the hydrothermal alteration of the mylonites in ali outcrops. A good example of the fault and its internai features is located in the normal limb of the synclinorium, approximately $2 \mathrm{~km}$ north of the town of Goiás on the GO-164 highway. At this outcrop, quartzites of the Serra do Cantagalo Sequence and metabasalts of the Digo-Digo Formation are separated by a sericite-quartz mylonite with abundant pyrite and chloritoid, derived from alteration of the latter. The outcrop also contains a conspicuous stretching lineation that is coaxial with the stretched pebbles of the Largo da Carioquinha outcrop. Another good example occurs in the inverse limb, where the fault marks the contact between the Sequence and the underlying Digo-Digo and Fazenda Cruzeiro Formations. Near and south of ZanzãFarm, the metabasalts are transformed into kyaniteor pyrophyllite-rich mylonites commonly with abundant centimetric chloritoid crystals and quartz veins.

It is noteworthy that to the north of the town of Goiás, a kllppe (Fig. 10) with cross-beddcd orthoquarlzites invaded by abundant quartz veins rests on tonalites of the Itapuranga Complex that in turn also occur as tectonic slabs within the quartzites. The lower contact of the klippe is a one-meter thick, tourmaliniferous mylonite derived from the gneisses. Tomazzoli (1985) correlates the rocks of the klippe to the Protcrozoic Araxá Group. The orthoquartzites in the klippe are, however, identical to those of the Serra do Cantagalo Sequence, and of the Serra Dourada Sequence that forms the mountain range of the same name located approximately $20 \mathrm{~km}$ south of the town of Goiás. The Serra Dourada Sequence rests on rocks of the Uva Complex by way of a tourmaline-bearing mylonite. Hence, the common allochthonous nature, similar lithologies, and hydrothermal alteration of the mylonites formed during tectonic transport suggest that the Serra Dourada and Serra do Cantagalo Sequences, as well as the klippe to the north of Goiás, may ali belong to the same stratigraphic unit.

This interpretation is supported by isotopic data of melavolcanic rocks of the Mossamedes Sequence, that overlics the Serra Dourada Sequence, and the $\mathrm{Sm} / \mathrm{Nd}$ model age of the Serra do Cantagalo Sequence. Mctavolcanic rocks of the Mossamedes Sequence yield a $\mathrm{Rb} / \mathrm{Sr}$ isochronic age of 1.933 $\mathrm{Ga}$ and a Sm/Nd modcl age of $2.20 \mathrm{Ga}$ (Fuck and Pimcntcl 1990, Pimentel et al 1996). On lhe other hand, $\mathrm{Sm} / \mathrm{Nd}$ data of the matrix of metaconglomerates of the Serra do Cantagalo Sequence yield a model age for the provenance of the clastic load, and the maximum age of deposition, of $2.36 \mathrm{Ga}$ (Resende 1998). Both units are therefore, Paleoproterozoic in age. METASEDIMENTARY STRATIGRAPHY OF THE FAINA GREENSTONE BELT: THE FURNA RICA GROUP Metasedimentary units of the Faina Belt belong to the Furna Rica Group. The group is subdivided, from the base to the top, into the Fazenda Tanque, Serra de São José, and Córrego do Tatu Formations, each formation containing two or three members.

Fazenda Tanque Formation The type section of the Fazenda Tanque Formation is localcd near lhe Tanque Farm, approximately $3 \mathrm{~km}$ to the west of the town of Jeroaquara (Fig. $4 \mathrm{~b})$. The section is the most complete of the entire belt and exposes three members.

The LowerMember is $100 \mathrm{~m}$ thick and is in tectonic contact with metavolcanic rocks of the underlying Serra de Santa Rita Group. It consists of orlhoquartzites and conglomeratic quartzites, locally with lenses of metaconglomerate. The orthoquarlzites are fine Io médium, in general lacking primary structures, bui may have planar-parallel bedding. These grade inlo conglomeralic quarlziles wilh clasls of rounded milky quartz. The lypical melaconglomerates are matrix-supported, lhe matrix conlaining variable proporlions of chlorile, sericite, and quarlz. On lhe average, the metaconglomerales contain $40 \%$ of clasls of the size of granules to blocks up to $30 \mathrm{~cm}$ in diameter, among which $70 \%$ are of ultramafic rocks, followed in relative proporlions by milky quarlz (Fig. 11). This indicales thal the unil was fed from a source-area lhal was partially composed of rocks lhal were similar Io lhe lower stratigraphic seclions of the supracruslal rocks.

In several places, lhe basal quartzile resls on a very fine, saccaroidal quarlzite-like rock consisling of $95 \%$ quartz, with minor fuchsile and lourmaline. Such rocks always occur beIween quarlziles and melakomaliiles and are inlerpreted as resulling from alleralion of the ullramafics.

The Intermediate Member is in sharp contacl with the Lower Member and consisls of approximalely $100 \mathrm{~m}$ of a monolonous sequence of lighl gray metapelites. The only outstanding feature of the melapelile sequence is the decreasing of lhe proporlion and of the size of quarlz wilh increasing slratigraphic hcighl.

The Upper Member is aboul $50 \mathrm{~m}$ thick and is composed of a carbonaceous schist horizon that gives place to an oxide fácies iron formalion and melacherl. The conlacl between lhe Intermediate and the Upper Members is gradational and given by lhe progressive increase of carbonaceous malerial in the metapcliles, indicaling increasing waler depth and restricted circulation towards lhe end of deposilion of lhe Fazenda Tanque Formalion.

Serra de São José Formation The type section of lhe Serra de São José Formalion is located in the Serra de São José range (Fig. 4b). The conlacl of Ihis unil with the Fazenda Tanque Formalion is sharp and conformable, lhe unil being subdivided inlo two members.

The Lower Member (Fig. 12) is $100 \mathrm{~m}$ to $150 \mathrm{~m}$ thick and comprises clean, white, and massive Io locally cross-bedded, orlhoquarlziles wilh lenses up Io $50 \mathrm{~m}$ thick of marble and carbonale-bearing schists. The marbles are pinkish, massive, and calcilic, and widely change laleral and vertical fácies lo melachert, iron-rich metacherl and oxide fácies banded iron formalion. Near Jeroaquara (Figs. 1 and 3), lhe Lower Member also conlains mclric lenses of kyanile-muscovile-quarlz schisls, kyanile-rich rocks, iron-rich quarlziles, and ankeritedolomile marbles, ali inlerpreted as hydrothermal alteration products.

The Upper Member is ai maximum $500 \mathrm{~m}$ Ihick and is its type section is located along lhe gravei road from Jeroaquara lo Lua Nova (Fig. 4b). The conlacl between the Lower and Upper Members is gradalional and given by lhe alternalion of meler Ihick layers of orlhoquarlziles of lhe former, and melapeliles of the latler, wilhin a Iransilion zone less lhan 10 $m$ Ihick. The melapeliles have a common layering given by quarlz-rich cenlimelric layers lhal grade inlo quarlz-poor melapelile. This grading indicates lhal the soulhweslern limb of the Faina synclinorium is inverled and the norlheaslern limb is normal.

Córrego do Tatu Formation The Córrego do Tatu Formalion is the upper unil of the Furna Rica Group. Its type section is localed along lhe Córrego do Talu (Fig. 4b), and the formation occurs wilhin the core of the Faina Bell synclinorium. When exposed, the contacl belween the Serra de São José and the Córrego do Tatu Formations is teclonic. Locally, lhe unit rests on metakomatiiles of lhe Manoel Leocádio Formalion via a ihrust faull. In view of ils leclonic contacts, 

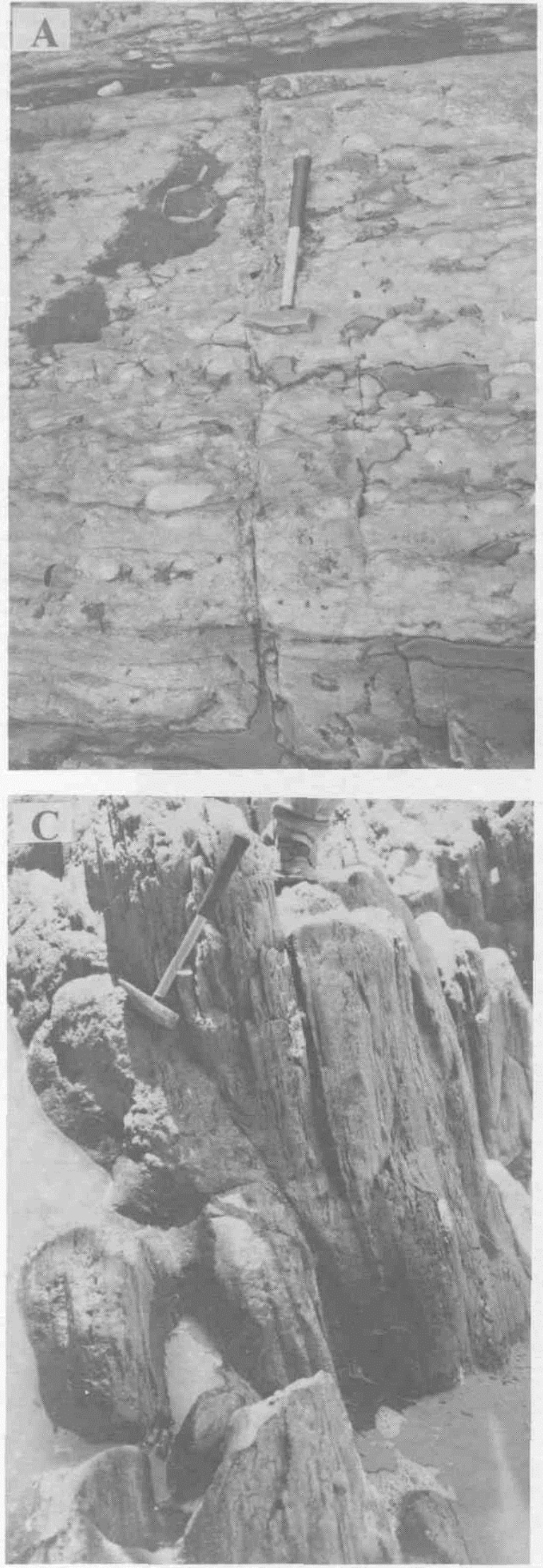

only part of the unit is prescrved as an array of aligned Icnscs at maximüm $170 \mathrm{~m}$ thick, and dividcd into two mcrnbcrs.

The Lower Member consists of approximatcly $100 \mathrm{~m}$ of puré pink to gray dolomite marble, with subordinate lateral

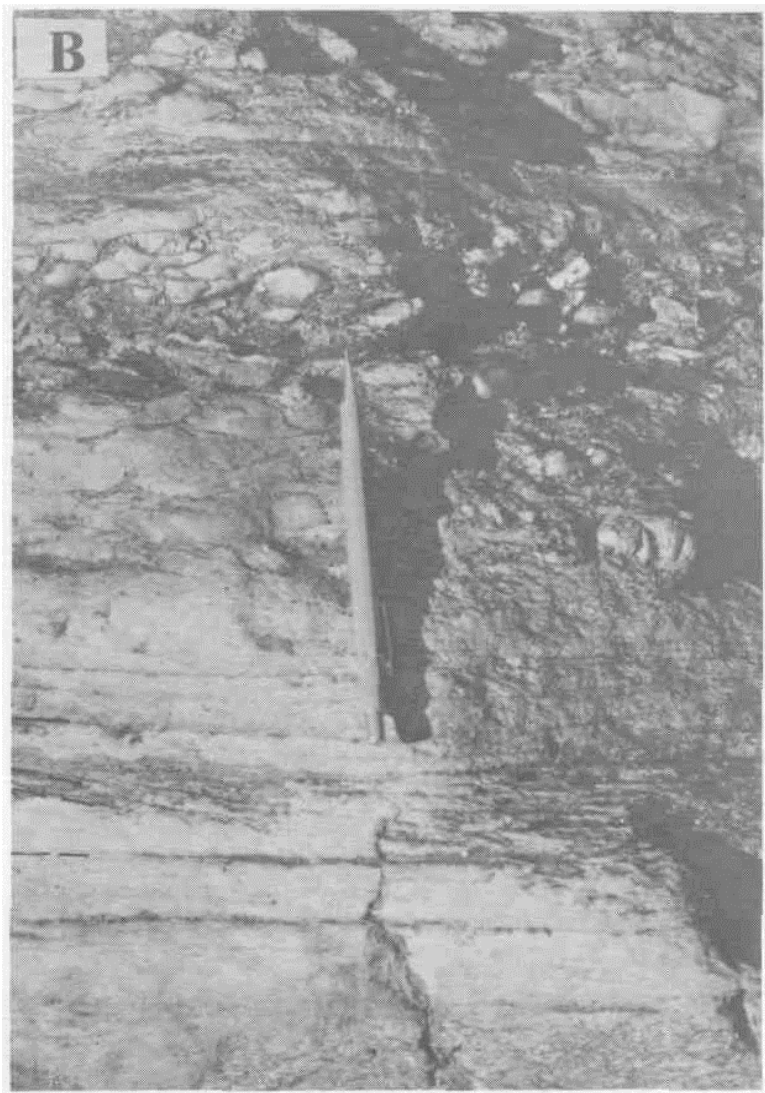

Figure 9 - Outcrop ofthe Serra cio Cantagalo Sequence at the Largo da Carioquinha, northern outskirts of the town of Goiás, (a) Clast-sitpported metaconglomerate with stretched pebbles and graded bedding to the top ofthe photograph. (b) Quartzites with cross and planar-parallel bedding below a metaconglomerate layer. (c) Cut-and-fill structiire between an upper metaconglomerate and a lower quartzite. Figura 9 - Afloramentos da Sequência Serra do Cantagalo expostos no Largo da Carioquinha, próximo à cidade de Goiás, (a) Metaconglomerado suportado por clastos estirados e mostrando granoclassificação no sentido do topo da fotografia, (b) Quartzitos com estratificação cruzada.e plano-paralela sotopostos a um banco de metaconglomerado. (c) Estrutura de corte-e-preenchimento entre um banco de metaconglomerado de topo e um quartzito basal.

fácies of mica- or quartz-rich marbles. The diagnostic feature of the marbles is a compositional layering (Fig. 13a) given by a rhythmic alternation of marble and millimetric to centimetric sheets of quartz, probably metachert. 


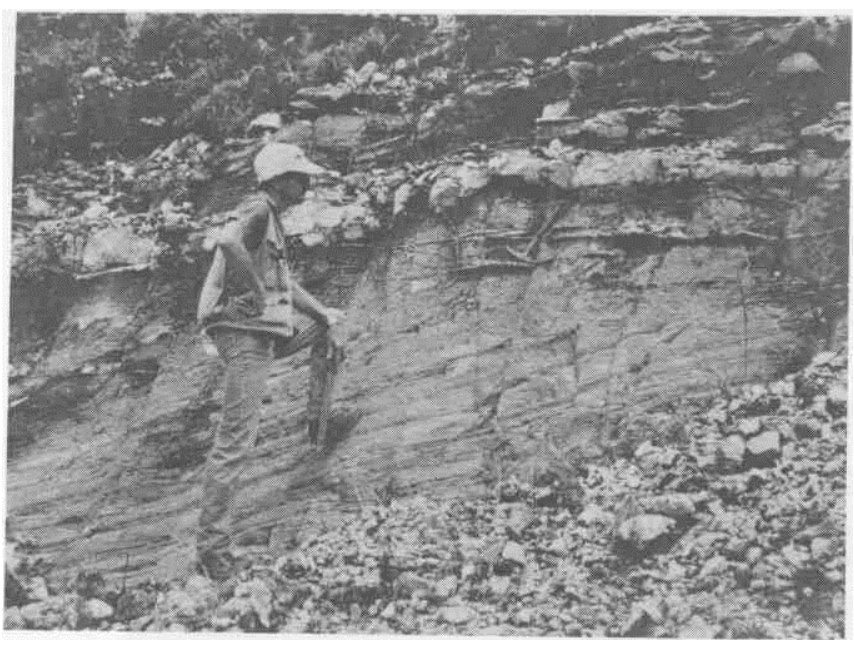

Figure 10 - Orthoquartzite ofthe klippe located north ofthe town of Goiás and correlated with the Serra do Cantagalo Sequence, showing well-preserved cross-bedding and quartz veins formed denoting intensefluid clrculaüon during thrusting.

Figura 10 - Ortoquartzito da klippe situada a norte da cidade de Goiás e correlacionado com a Sequência Serra do Cantagalo, mostrando estratificacão cruzada bem preservada e veios de quartzo formados e denotando intensa circulação de fluidos durante o transporte tectônico.
The Upper Member (Fig. 13b) is in sharp, lateral and vertical contact with the Lower Member and occurs mainly at lhe northwestcrn tip ofthe belt. The unit consists of hematite, commonly specularite, banded iron formations, locally with metric to centimetric layers of puré or iron oxide bearing metachcrt.

The Córrego do Tatu Formation is lithologically similar to the Morro Escuro Sequence described by Jost et al (1989) as lectonically overlying the southern portions of the Guarinos Grcenstone Belt (Fig. 1). The Morro Escuro Sequence also consists of banded iron formations and marbles. However, it differs from the Córrego do Tatu Formation by the occurrence of basal, clast-supported, metaconglomerates that may correspond to proximal deposits ofthe more distai quartzites ofthe Lowcr Member of the Serra de São José Formation. The allochtonous naturc of lhe Morro Escuro Formation and the tcclonic contacts of lhe Córrego do Tatu Formation leads to the assertion that the later may too bc, at least, para-allochtonous.

OTHER MAFIC-ULTRAMAFIC ROCKS Several mi nor mafic and ultramafic bodics occur dispersed within the Uva and Itapuranga Granite-Gneiss Complexes. In the past, these wcre interpretcd as feeders ofthe komatiites and basalts of the greenstone belts, based on the assumption that the granitoids were lhe basemcnt of the supracrustals. New field data show that thesc bodies vary in composition, state of

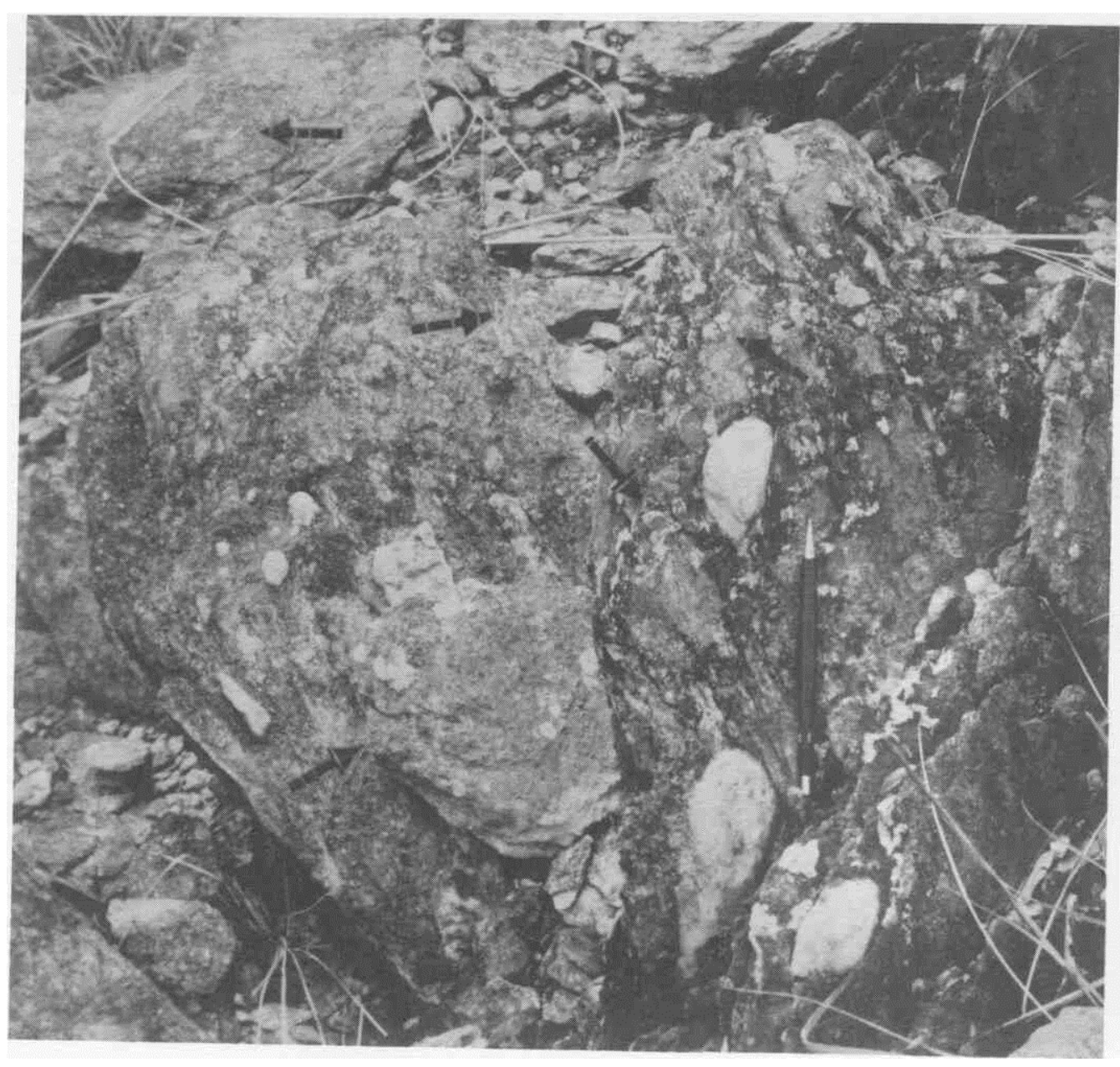

Figure JJ - Metaconglomerate of the Lower Member of the Fazenda Tanque Formation. Larger idtramafc clasts indicated by arrows. Large rounded clasts are of milky quartz. Small light clasts are also of ultramafic rocks.

Figura 11 - Metaconglomerado do Membro Inferior da Formação Fazenda Tanque. Clastos grandes indicados pelas flechas são de rochas ultramáficas. Clastos grandes, brancos e arredondados são de quartzo leitoso. Clastos menores e claros são de rochas ultramáficas. 
deformation, shapc, and sizc, and may be groupcd into at Icast three major categories:

1 - Dominantly ultramafic and minor mafic schist bodics from the size of a fist up to sevcral hundred meters long, wilh a shape that varies from irregular to tabular and resembling dykes at the surface. Some of these rocks contain intercalations of banded iron formations, ali have a conspicuous mctamorphic foliation that changes orientation considerably and that contrasts wilh the lack of foliation of the enclosing granitoids, and they are interpretcd as rcmnants of supracrustal rocks correlated with the greenstonc belts. Thcy occur either as xenoliths, sliccs imbricated in thrust faults, or as klippcs.

The xenoliths are rootless, and commonly have a rim of contact metamorphism and metasomatism. This is indicatcd, for example, by the transformation of the metamorphic mineral assemblage of the ullramafics into phlogopite, or the recrystallization of mctamanc rocks. Xenoliths of supracrustal rocks are particularly abundant near the contact of the Goiás Greenstone Belt with both the Uva and the Itapuranga Complex granitoids.

Slices of supracrustal rocks occur in shallow-dipping mylonites ofthe major thrust faults that affcct both the granitoids and the greenstone bclts. Good cxamplcs of these slices crop out along the gravei road from the town of Buenolândia, norlh towards the highway GO-164.

Klippes in general consist of ultramafic and mafic rock bodies with a flat-lying foliation. When exposed, the contact of these rocks wilh the undcrlying graniloids is a narrow, sub-horizontal, zone of mylonite. They are parlicularly frequent in Uva Complex and sustain the top of the hills of the complex landscape. In plan view, their shapc is irregular and varies in size from a few lens up Io evenlually lhousands of square melers.

2 - Dolerile and pyroxenite dykes and stocks that inlrude the Uva and the Itapuranga Complexes. The slocks have, in general, slrongly folialed margins and igneous lexlurcs preserved towards the core, and are invariably saussuritic. Both dykes and stocks appear Io abruptly lerminatc at lhe grcenslone conlacts. This contact relationship Icd carlicr aulhors Io inlerpret these bodies as bclonging to the basement complcxes or as feeders ofthe supracrustals. The absence of pcnetralion inlo the supracrustals is probably due to the competcncy differences betwecn lhe graniloids and the supracrustals. Despile bcing relalively common in the granitoid Complexes, fcw are known to intrude lhe supracruslal sequences. This probably reflccls the lack of detailed mapping/exploralion, addcd Io the difficullies in dislinguishing lhem from the Archacan komaliiles and melabasalls owing Io their similar wcalhering producls. The dykes occur as swarms slriking roughly $\mathrm{NS}$ and $\mathrm{N} 60^{\circ} \mathrm{W}$. Geochronological $\mathrm{Rb} / \mathrm{Sr}$ dating of the dykes by Tomazzoli $(1992,1997)$ yield an age range of 2.0 Io $1.8 \mathrm{Ga}$. We inlcrprel lhese rocks as, in part, intracratonic inlrusions of lhe early phases of the crustal extension that culminated in the largc-scale Palaeoproterozoic inlracontinental rifl-syslem of lhe Soulh American Plalform, as proposed by Nilson et al (1994), Winge (1995), and Brilo Neves (1995). As rcporlcd by Kuyumjian (1998), they may also be, in pari, mafic dykes relaled Io the crustal exlension that resultcd in the breakup of Gondwanaland during the Mesozoic.

3 - Rare lamprophyres of kimberlilic affilialion (alnõiles) lhal crop oul in the headwalers of the Córrego da Onça (METAGO 1985) and have rccently becn inlersected in drilling by Mineração Jenipapo S.A. (Grani A. Osborne - pcrsonal communicalion) in lhe Serra do Cubatão. Both localities are situalcd ai the soulh of the Faina Bell. The fresh alnõites conlain $30-50 \%$ biolite/phlogopite, $30 \%$ carbonate, $2 \%$ pcrovskilc, and varying amounls of diopside, apalile, and scrpcntine, and may locally contain fragmenls of quartzscricite schist incorporated from the supracruslal country rocks. Since lhesc rocks are completely preserved from deformation, it is poslulalcd lhal they may bc correlated wilh the Uppcr Crctaceous, alkalinc suites of Brazil, such as the Iporá Group that outcrops in various localilies wilhin the Goiás magmatic are.

THE FAINA FAULT In the past, lhe Goiás and Faina Grccnslonc Bells have becn considercd as onc single sequence of supracruslal rocks, offsel by the Faina Fault. As above dcscribcd, lhe bclls have conlrasling sedimcnlary records and, Ihcreforc, cvolved under dislincl palcogeographic scltings. This leads lhe aulhors Io considcr and inlcrprel the role of lhe Faina Faull.

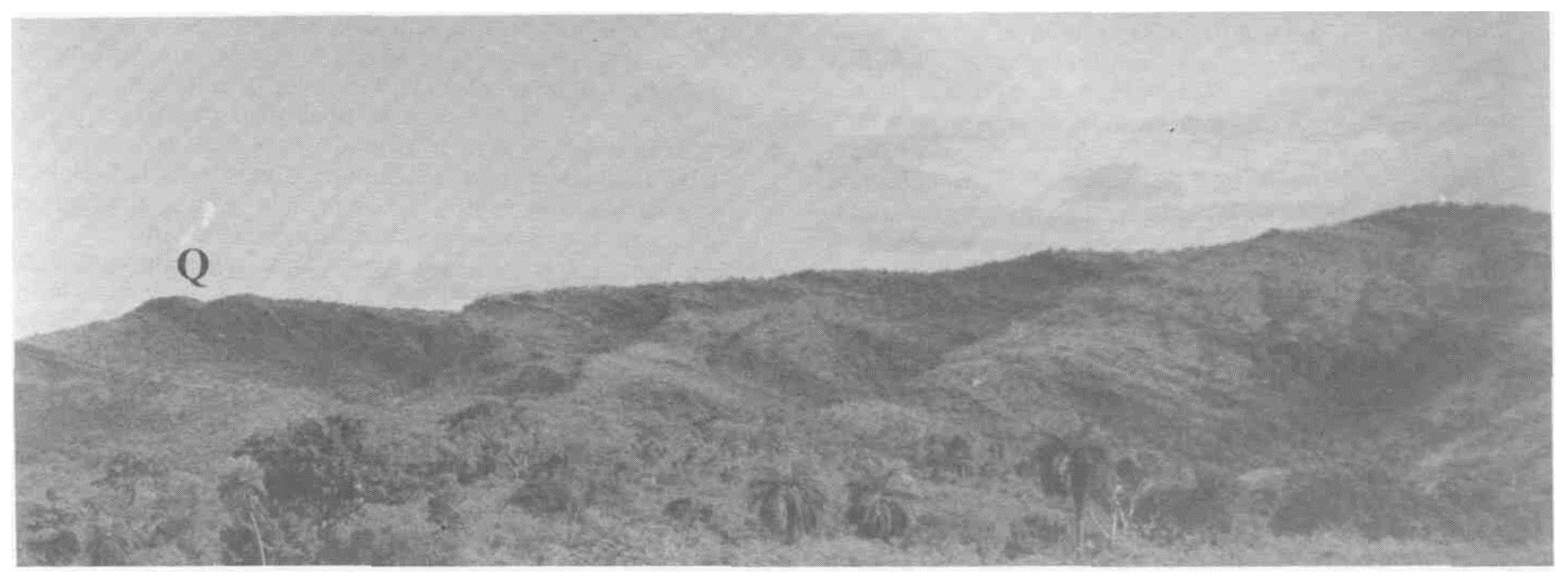

Figure 12 - Panoramic view to the SE ofthe Serra de São José Formation showing the quartzite beds ofthe Lower Member (Q) overlain to the right, by the thick sequence of metapelites with thin quartzite intercalations ofthe Upper Member.

Figura 12 - Visão panorâmica para SE da Formação Serra de São José, mostrando os quartzitos do Membro Inferior (Q), sotopostos a espessa sucessão de metapelitos e finas camadas de quartzito do Membro Superior. 

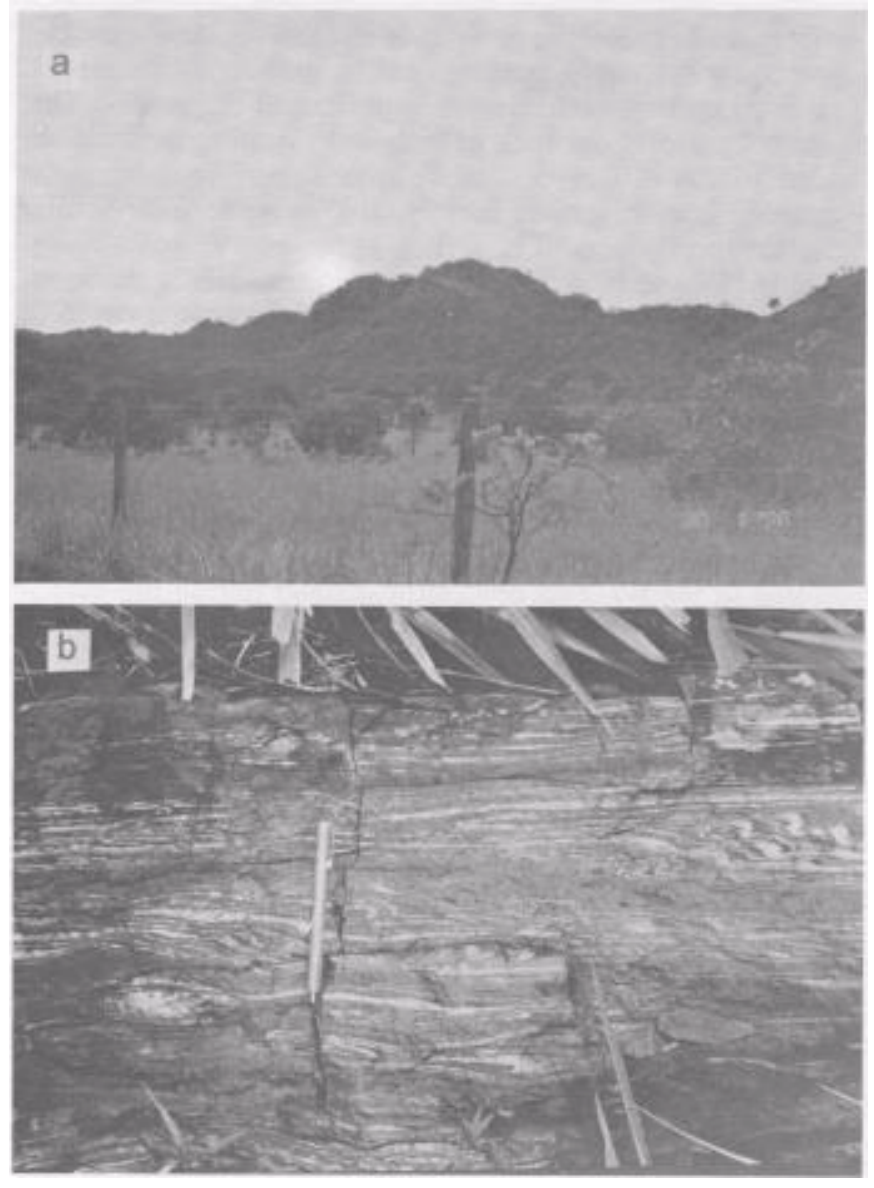

Figure 13 - Outcrop of (a) typicai dolomite marble of the Lower Member, and (b) banded iron formation oftlie Upper Member of the Córrego do Tatu Formation, Furna Rica Group, Faina Greenstone Belt.

Figura 13 - Afloramentos de (a) de mármores dolomíticos e (b) formação ferrífera do Membro Inferior típicos do Membro Superior, da Formação Córrego do Tatu, Grupo Furna Rica, Greenstone Belt de Faina.

In the past, the Faina Fault was interpreted as a splay of the large-scale, deep-seated, sinistrai Moiporá-Novo Brasil Shear Zone (Fig. 14). In the south, near the town of Cachoeira de Goiás, the shear zone emerges from underncath Siluro-Dcvonian sedimentary rocks (Furnas Formation) of the Paraná Basin as a prominent north-south vertical structure, more than $200 \mathrm{~km}$ long, and more than $1 \mathrm{~km}$ wide, passing near Mcssianópolis, Novo Brasil, and Itapirapuã. Gcochronological data by Pimentel et al. (1996) indicate that, towards the south, the shear zone cuts supracruslal rocks and gncisses of a Neoproterozoic magmatic are. North of Messianópolis, the shear zone juxtaposes Neoproterozoic metavolcanic are rocks to the west with Palaeo- to Mesoprolerozoic metasedimentary, locally metavolcanics of the Mossâmedes/Serra Dourada Sequences to east. From the Serra Dourada Range to the north, it separates the Neoproterozoic magmatic are to the west from the Goiás Archaean terranes to the east.

Near and to the norlh of Messianópolis, the shear zone develops a series of splay faults. We bclieve that the apparcnt splay faults clearly visible in remotc scnsing images are related to the displacement along the Moiporá-Novo Brasil main shear zone and are of two categories. One consists of thin-skinned, shallow, south-dipping thrust faults and related vertical NS tear faults. Other consists of vertical, real splay faults, resulting from energy dissipation along the MoiporáNovo Brasil Shear Zone.
The most prominent thrust faults are, from south to north, the gently curved contacts successi vely (l) of the Neoproterozoic metavolcanic are rocks onto the Palaeo- to Mesoproterozoic Mossâmedes Sequence, (2) of the Mossâmedes Sequence onto the Serra Dourada Sequence, and (3) of the Serra Dourada Sequence onto the Archaean terranes. The tectonic transport of thc Serra Dourada Sequence onto the Archaean terranes is evidcnced by a lower tourmaline-bearing mylonite that crops out at approximately two-thirds above the base of the Serra Dourada Range and by scveral remnant klippes to the north during the southward crosional receding escarpmont.

The most prominent tear fault strikes NNE and cuts the thrust fault of thc contact between rocks of lhe southern magmatic are and thc Mossâmedes Sequence. The fault passes just to the east of São Luis de Montes Belos, and is marked by a wide zone of mylonite that was, in the past, mapped as a narrow cxtension of the Mossâmedes Sequence. This fault hosts thc exhausted Aurilândia gold dcposit of Mineração Jenipapo SÁ. Minor and cvident tear faults crosscut and displace the Serra Dourada Sequence along the scarp of the Serra Dourada Range.

Splay faults are more prominent to the east than to the west of thc Moirporá-Novo Brasil Shear Zone. Only one fault is evident in the western block. Thc fault trends NNW, hás a sinistrai displacement, and passes near Fazenda Nova, dissipating south of Jussara. The eastern block hosts lhe majority of Ihcsc faulls, one of lhesc being lhe Faina Fault.

The Faina Fault, in particular, is a vertical structure thatcan bc followed in remole scnsing images from ils soulhern end norlhwards for aboul $180 \mathrm{~km}$ unlil the soulhern lip of the Crixás Greenslone Belt, in the northern porlion of the Archaean terranes of Goiás. The fault hás an ENE trace and a right lateral displaccmenl, which is in conlrasl wilh lhe NNE Irajeclory and sinistrai displaccmenl of the majority of other splay faulls hosled by the Archaean lerranes. Addilionally, the Faina Fault extcnds inlo lhe Goiás and Faina supracruslals rocks as scveral parallcl, north-dipping, normal faults containing sub-horizonlal slickensides, suggesting lhat il may be a pre-exisling structure thal was reaclivated during lhe Palaeoprolerozoic and lalcr deformations, as a slow-releasing, stepover fault array.

The marked contrasls in lhe sedimentary records between lhe Faina and Goiás Greenstone Belts suggesl lhal lhe fault may rcprescnl a syn-scdimcnlary growlh faull or even an original rifl transform faull. Wc suggesl lhal the sinislral NS-trcnding shear zones, the splay faults, and the norlh-verging thrusl faults are ali related to a north-soulh compressive evenl, probably of Palaeoprolerozoic age, lhal were further rcactivalcd during the Meso- and Ncoprolerozoic. Many of the NS faults may represem bounding lear faulls, lhe stacked thrusl shccls reprcsenting lhe associated leading conlraclion faull array. Wc also suggesl thal This dcformalion event may have becn responsible for lhe leclonic transport and subsequent infolding of the Serra do Canlagalo Sequence wilhin lhe Goiás Greenslone Belt, and thal Ihis sequence is probably a pari of lhe Serra Dourada Sequence.

\section{EVOLUTION OF THE GOIÁS AND FAINA GREEN- STONE BELTS Preliminary Considerations}

The only availablc radiometric data of the Goiás and Faina Greenstone Belts (Table 1) were oblained by Resende (1998), and consisl of Sm/Nd model ages (TDM) of melasedimenlary rocks of several slraligraphic leveis. These dala suggesl thal the provenance of the delrilal load, and lhal lherefore lhe maximum age of sedimentation of the analyzed units is between 3.2 and $2.8 \mathrm{Ga}$. Thus, it is assumed lhal the basin slage of the Goiás and Faina bells began ai lhe earliesl by $3.2 \mathrm{Ga}$, and thal the bells are conlemporaneous, bui nol necessarily 
synchronous. These assumptions, on their turns, require additional and more reliable isotopic data.

The fragmentary nature of the remaining supracrustal sequences inhibits any speculations on the original dimensions of lhe basin. There is also, só far, no evidence about lhe nature of the Archaean crust within which the basin was installed. The contact between rocks of the Itapuranga and Uva Complexes and the Goiás and Faina Belts are either tectonic or intrusive. Many if not ali of the faults are flat-lying or steep thrust faults indicating that the greenstone belts are allochtonous. The $\mathrm{Rb} / \mathrm{Sr}$ and $\mathrm{Sm} / \mathrm{Nd}$ radiometric data (Tassinari et al. 1981,FuckandPimentel 1990,Tomazzoli 1992,Pimentel et al. 1996) of the Itapuranga and Uva Complexes have só far not detected rocks older than $3.1 \mathrm{Ga}$. This age is at least $100 \mathrm{Ma}$ younger than the model age of the provenance of the lowest portions of the sedimentary sequcnce of both belts. Consequently, these complexes cannot be interpreted as the original basement of the Archaean supracrustal sequences. The oldest granite-gneiss complexes are probably only remnants preserved within other granitoids of the age range from 2.9 to $2.4 \mathrm{Ga}$ that make up about $80 \%$ of the Archaean terranes of the southern portions of the Goiás Massive. On the other hand, more and more evidences from Archaean terranes of other continents are demonstrating that the so-called 'basement' complexes are, in fact, metamorphosed, plutonic complexes, synchronous with the Greenstone Belts themselves (see De Wh \& Ashwall 1997 and references therein), as we also interpret the oldest gneisses of the studied área.

The Volcanic Phase The nature of the volcanic packages of the Serra de Santa Rita Group, common to both belts, indicates that their basin stage began under a similar exten- sional regime. Volcanism began with komatiites and progressed to basalts, which, in turn, gave place to a felsic pyroclastic event in the Goiás Belt. This bimodal character of the volcanism Goiás Belt hás this far not been observed in the other belts.

Geochemical data of the komatiites obtained by Tomazzoli (1985) and Profumo (1993) show that, from base to top, the section varies from komatiites to komatiitic basalts. Excluding the komatiitic basalts, the komatiites show a conspicuous decrease i $\mathrm{n} \mathrm{MgO}$ and increase in $\mathrm{Ca}$ and $\mathrm{Al}$ upwards in the stratigraphic section, suggesting that volcanic products responded to a fractionation path that can be attributed to decreasing depths of magma generation with time and within one same mantle plume. Geochemical data (Mineração Jenipapo S.A. - unpublished data) of the Goiás and Faina metabasalts show that they are tholeiites correlated with extensional tectonic regimes.

The relicts of primary structures and textures in the metakomatiites and metabasalts indicate that the volcanism took place under sub-aqueous conditions. The intercalations of banded iron formation and metachert, with or without carbonaceous schists, indicate sedimentation during periods of quiescent volcanism.

To date, there is no explanation for the thickness differences of the metakomatiite sections between the Goiás and the Faina Belts, nor the decreasing thickness of the metabasalts from southeast to northwest in the Faina Belt. These are preferably interpreted as the effect of tectonic deformation, but may in part also be explained by different duration or intensity of the volcanic activity.

The volcanic piles of the Goiás and Faina Belts are overlain by the respective sedimentary sequences. The nature and

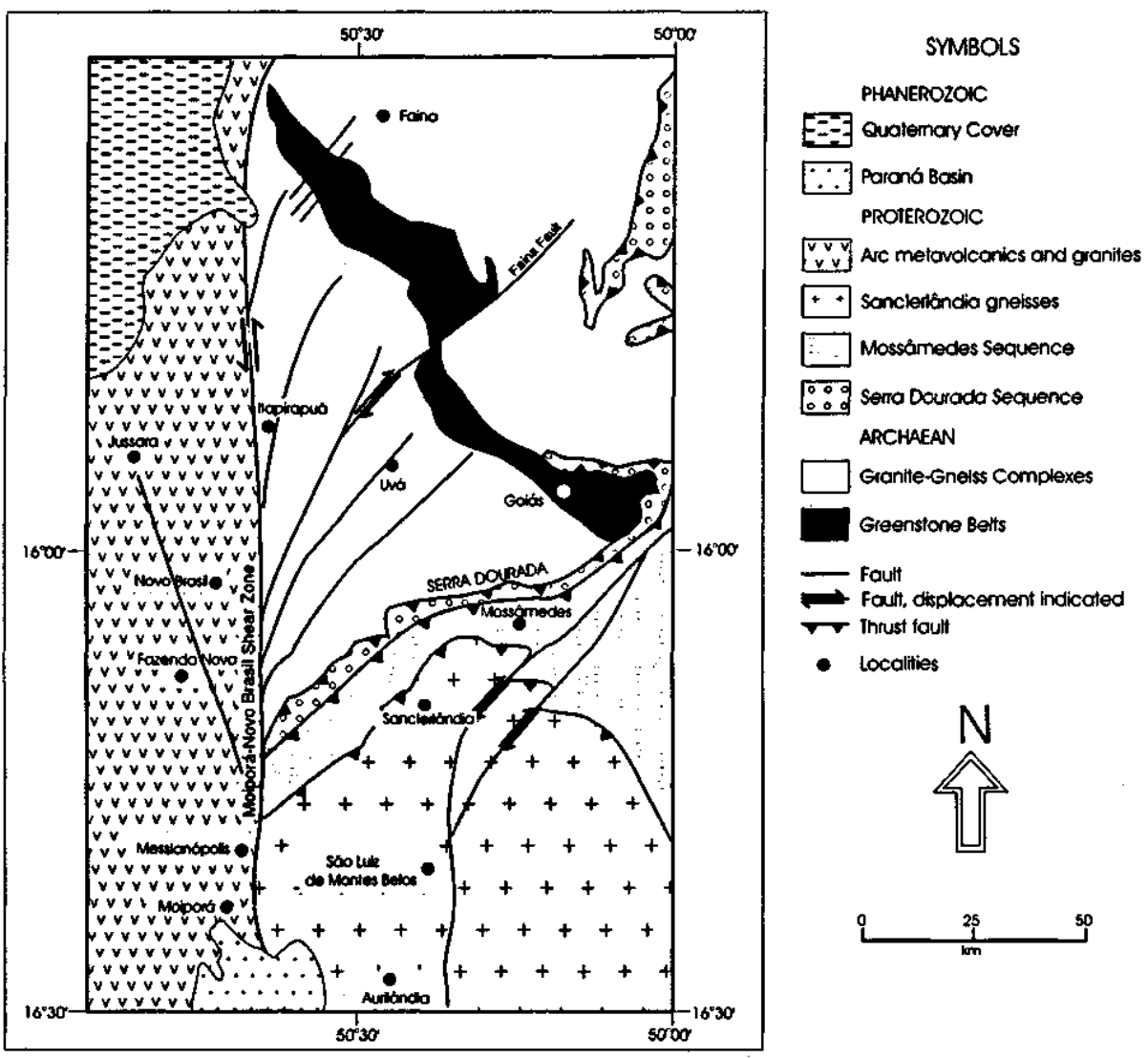

Figure 14 - Geologic map showing the major lithologic units adjacent to the southern portions ofthe Goiás Archaean terranes as well as the Moiporá-Novo Brasil Shear Zone and its main splay faults and related thrust faults.

Figura 14 - Mapa geológico mostrando a distribuição das maiores unidades litológicas adjacentes à porção meridional dos terrenos arqueanos de Goiás, bem como a zona de cisalhamento Moiporá-Novo Brasil e falhas de desfiamento e de empurrão associadas. 
course of sedimentation in each belt indicate that their scdimentary histories were different since their inception, and, therefore, must be treated separately.

Sedimentation in the Goiás Belt In the Goiás Belt, the sedimentary record started while volcanism was still active, as indicated by the intercalations of carbonaceous schisls within the top of the metabasalts and the felsic pyroclastics before the prevalence of the carbonaceous schists typical of the Lower Member of the Fazenda Limeira Formation. The relationships between the metabasalts and carbonaceous schists of the Goiás Belt are idcntical to those between similar units of the Crixás Belt (Fig. 1), as described by Theodoro (1995).

Theodoro (1995) and Fortes (1996) concluded from textural, structural, and carbon isotopic data that the carbonaceous schists of Crixás are metapelites wilh a prominent contribution of organic matter, probably derived from the activity cianobacteriae. The carbonaceous schists of the Lower Member of the Limeira Formation are here interpreted as having the same origin and, therefore, rcpresenting an euxenic environment. The eventual mctachert intercalations in these schists may be attributed to momcntary exhalations.

The succession from carbonaceous schists of the Lower Member of the Fazenda Limeira Formation into the metacherts, iron formations, calcschists and the marbles of the Upper Member implies that the initial euxenic environment was gradually replaced by chcmical sedimentation within shallower and more oxygenated waters. The origin of the marbles is still uncertain. However, if a correlation between these marbles and those associated with carbonaceous schists of the Crixás Belt may be entertained then both may bc explained under similar environmental conditions. However, many of the Crixás Belt marbles are rich in ooliths and algal mats (Theodoro 1995), which are absent in the Goiás Belt. The lack of primary structures and the association of the marbles of the Goiás Belt wilh chert and banded iron formations implies that the rocks of the Uppcr Member were dcposited belo $\mathrm{w}$ the depth of storm waves, and thus i n deeper waters than at Crixás.

The last sedimentary event in the Goiás Belt is represented by the metarhythmites and feldspathic quartzites respectively of the Lower and Upper Members of the Fazenda Cruzeiro Formation. The rocks of the Fazenda Cruzeiro Formation are in common tectonic contact with many of the older units. This suggests that the unit probably deposited in fault-bounded depressions exposing several underlying volcanic and sedimentary units. The local sharp, but non tectonic contact between the quartzites of the Upper Member and the metachert belonging to the lower portion of the Upper Member of the Fazenda Limeira Formation suggest that the clastic deposition took place suddenly after the topmost chemical sequence.

The Lower Member of the Fazenda Cruzeiro Formation resembles a turbidite sequence. Actually, we prefer to use the textural/structural terminology than the genetic term. This preference derives from the absence of classic turbidite structures, other than just the positive grain size variation between lower quartzites and upper metapelites of the individual rhythms.

The rhythm given by the alternation of graded sets of sand and clay protoliths organized in successive, upwards-fming cycles of the Lower Member contrasts with the sequence of centimetric layers of fine sand blankets, with cross-bedding and cut-and-fill structures, without upwards-fining of the Upper Member. This suggests that the latter not only represent the ultimate filling of the depressions containing the underlying rhythmites, but also that they were deposited in shallower waters with enough energy to carry farther most of the clay fraction, preventing from vertical, rhythmic layering, but probably promoting lateral grading.

In spite of the uncertainties about the depositional environment and tectonic significance of the rocks of the Fazenda Cruzeiro Formation, it unquestionably represents a marked change in the depositional regime during the late stages of the Goiás Belt evolution.

Sedimentation in the Faina Belt The sharp contact between the underlying metabasalts of the Digo-Digo Formation and the metapsammites of the Fazenda Tanque Formation indicates that the sedimentation began long after the definitive closing of the volcanic activity. In addition, the metaconglomerates with clasts of ultramafic rocks probably derived from lhe underlying stratigraphic leveis are clear evidence that deposition took place on an erosional unconformily represenling a hiatus of unknown duration.

Once started, sedimentation evolved to build up the Furna Rica Group. The sedimentary record of this group contains two major iransgressive cycles.

The firsl cycle is regislered by lhe upward-fining sequence of the Fazenda Tanque Formation. The deposition of the unit starled wilh near-shore, homogeneous, clean sands, gravelly sands, and gravei lenses, progressing inlo pelites followed by euxenic pelites, and chert and iron-rich cherts at the top of the unit. Thus, lhe Fazenda Tanque Formalion evolved under a marine Iransgression wilh progressively deeper walers. The lack of laleral continuity of the upper deep-water sedimentary record indicates thal their protoliths were probably deposited in depressions with restricted water circulation.

The second cycle began with a regression as evidenced by lhe quarlzites of the Lower Member of lhe Serra de São José Formation, which overly the deep-water, metasedimentary rocks of the Fazenda Tanque Formation. The occurrence of lenses of iron formation and marblein these quartzites indicate thal local siles of low energy accompanied the deposition of the regressive sands.

Regression was followed by transgression, wilh deposition of a fine package of sands. Both regressive and transgressive sands are grouped inlo lhe Lower Member of the Serra de São José Formation. They may, however, be distinguished through lhe occurrence of marble, iron formation and minor carbonaceous quartzite lenses in lhe former, lhat are absent in the latter. The quarlziles gradually give place to a thick sequence of melapeliles of the Upper Member of the Serra de São José Formation. The pelitic sedimentation was subslituted by a long period of chemical deposilion represenled by the marbles and banded iron formations of the Córrego do Tatu Formation, which in turn indicale deeper-water conditions.

The $\mathrm{Sm} / \mathrm{Nd}$ model ages of the melapelites of lhe Upper Member of lhe Serra de São José Formation (Faina Belt) and the metarhylhmiles of lhe Fazenda Cruzeiro Formation (Goiás Belt) are identical at about $2.8 \mathrm{Ga}$. This suggests that the latter may represent the deep-water equivalents of the former, probably due to overflow of the clastic load at the shelf edge, probably marked by the Faina Fault.

Clastic load provenance based on preliminary geochemical data The evaluation and interpretation of major, minor and trace element data of the clastic metassedimenlary rocks of lhe Goiás and Faina Belts are still in course by two of the aulhors (M. G. Resende and H. Jost). Preliminary rcsults show lhat major element oxides, olher lhan $\mathrm{SiOz}$ are, in decreasing order of abundance, $\mathrm{Al}_{2} \mathrm{O}_{3}, \mathrm{MgO}, \mathrm{Fe}_{2} \mathrm{O}_{3}{ }^{*}, \mathrm{~K}_{2} \mathrm{O}$, $\mathrm{CaO}$ and $\mathrm{Na}_{2} \mathrm{O}$, in the lower unils, such as lhe carbonaceous schists of the Fazenda Limeira Formation (Goiás Belt) and the quartzites and metapelites of the Fazenda Tanque Formation (Faina Belt). The upper units, such as the rhythmites of the Fazenda Cruzeiro Formation (Goiás), the quartzites and 
metapelites of the Serra de São José Formation (Faina), and the quartzites of the Serra do Cantagalo Sequence contain $\mathrm{Al}_{2} \mathrm{O}_{3}, \mathrm{KaO}, \mathrm{Fe}_{2} \mathrm{O}_{5}{ }^{*}, \mathrm{Na}_{2} \mathrm{O}$ e $\mathrm{CaO}$, in decreasing order of abundance. Thus, lhe clastic loads of the lower sedimentary sections derived from source-areas richer in $\mathrm{MgO}$ and $\mathrm{CaO}$ than the upper sections that derived from source áreas richer in $\mathrm{K} 2 \mathrm{O}$ and $\mathrm{Na} 2 \mathrm{U}$, and lherefore more granitic.

Table 2 shows the average result of provenance modeling of the clastic loads by means of trace element data. The composition of the carbonaceous schists of the Fazenda Limeira Formation (Goiás Belt) and the quartzites and metapelites of the Fazenda Tanque Formation (Faina Belt) can be explained by a source área composed mainly of mafic and ultramafic rocks. In the later, this provenance is clearly indicated by the abundance of ultramafic and mafic clasts in the lower metaconglomerates (Resende 1998). On the other hand, the rhythmites of the Fazenda Cruzeiro Formation (Goiás Belt) and the Serra de São José Formation (Faina Belt) formcd at the expense of a clastic load derived from a more granitic source área. In details, the contribution of an ultramafic component is much more prominent in the lower units and along a thicker stratigraphic section of the Faina Belt than in the Goiás Belt.

The Sm/Nd model ages (Tol0 of about 3,2-3.17 Ga combined with the provenance data of the lower seclions of the metasedimentary sequences of the Goiás and Faina Belts, suggest that komatiites and basalts may be of that age range. On the other hand, the most plausible felsic sediment component of the upper sections may be tonalitic gneisses with a $\mathrm{Sm} / \mathrm{Nd}$ model age within the range of 3.10 to $3.05 \mathrm{Ga}$, similar to those of the Uva Complex dated by Pimentel et al. (1996) and Potrel et al. (1998).

On average, the composition of the Serra do Cantagalo Sequence can be explained by a provenance dominated by granitoids, with lesser ultramafic and mafic rocks.

CONCLUSIONS Despite of the state of deformation and of the many uncertainties induced by the structural framework of the Goiás and Faina Greenstone Belts, many of the original relationships among most of the major rock types can be resolved by detailed lithologic mapping and interpretation. As compared to former, simpler stratigraphic schemes, the new proposed formal and more complete stratigraphic models yield a more comprehensive evolution of cach bclt.
Since the onset of the 1980's, it hás been a common sense that bolh belts have lower metakomatiites, middle metabasalts, and upper metasedimentary sequences. The metal logenetic potential and the petrologic importance of the lower metavolcanics are probably the major reasons for the former stratigraphic models to underestimate the metasedimentary record and to contemplate only the metavolcanic rock typcs.

It is clear that the early evolution of both belts was controlled by the same extensional, tectonic regime. The belts do not differ in their lower ultramafic and mafic volcanic sections. However, the contrasting sedimentary piles unquestionably indicate that they evolved under different paleogeographic settings, water depth regimes, and sedimentary environments. The Faina Belt evolved as typical, two-cycle sandstone-pelite-carbonate shelf, which progressively deepened, with each cycle closing with the deposition of banded iron formations. The Goiás Belt evolved as deep water, euxinic, shallowing-up basin, suddenly receiving a pile of siliciclastic rhythmic load. The Faina Fault probably separated both paleogeographic settings. The new data from the Goiás and Faina Belts, along with those of the Crixás, Guarinos, and Pilar de Goiás belts dcscribed by Jost \& Oliveira (1991), now allow a better understanding of the variety of sedimentary environments that prevailed during the Late Archaean presently preserved in the State of Goiás.

Post-depositional deformation of the Goiás and Faina belts look place in several thrusting episodes, probably since the Late Archaean to Late Proterozoic. It is however certain that their synclinorium shape is not Archaean, but at maximum Palaeoproterozoic, as indicated by the structural relationships between the Goiás Belt and the Serra do Cantagalo Sequence.

Aknowledgements We extend our grateful thanks to the following groups and individuais: Conselho Nacional de Desenvolvimento Científico e Tecnológico - CNPq for a Research Grant to H. Jost (Proc. $\mathrm{n}^{\circ} 35.1597 / 97-2$ ), and for funding part of the field works (Proc. $\mathrm{n}^{\circ}$ 52.0682/94); Mineração Genipapo SÁ of Western Mining Company, for support during field work and disclosing drillhole and field data; Geoscience Institute of the University of Brasília for the facilities during the course of the Ph.D. Degree of M.G Resende, of which the contents of this paper are a part; to two anonymous referees, and to Franciscus J. Baars for their criticai review of the manuscript and helpful suggestions.

\section{REFERENCES}

Brito Neves, B.B.; Martins de Sá, J.; Nilson, A.A. \& Botelho, N.F. 1995 - A Tafrogênese Estateriana nos blocos paleoproteozóicos da América do Sul e processos subsequentes. CPMTG-IGC-UFMG, Genuínos, $3(2): 1-21$.

Castro Júnior, F.P. \& Talhari Júnior, J.R. 1988. Geologia da região de Faina (GO), Área $I V$. Unpublished Graduation Report, Universidade de Brasília. $140 \mathrm{p}$.

Costa, E.M.A. \& Castro, L.C.G. 1988. Geologia da região de Faina (GO), Area VII. Unpublished Graduation Report, Universidade de Brasília. $135 \mathrm{p}$.

Danni, J.C.M.; Dardenne, M.A. \& Fuck, R.A. 1981. Geologia da região da Serra da Santa Rita e Sequência Serra de Cantagalo: Simpósio de Geologia do Centro-Oeste, 1, Goiânia, Anais..., p. 265-280.

De Wit, MJ. \& Ashwal, L.D. (editors) 1997. Greenstone Belts. Oxford University Press, 809 p.

Fortes, P.T.F.O. 1996. Metalogênese dos depósitos auríferos Mina 111, Mina Nova e Mina Inglesa, Greenstone Belt de Crixás, GO. Unpublished Ph.D. Thesis, Universidade de Brasília, 176p.

Fuck, R.A. and Pimentel, M.M. 1990 Geocronologia de rochas gnáissicas da área de Mossâmedes-Sanclerlândia, Goiás: Congresso Brasileiro de Geologia, 36, Natal, Resumos Expandidos, p.333.
Jost, H. \& Oliveira, A.M. 1991. Stratigraphy of the greenstone gelts, Crixás region, Goiás, Central Brazil. Journal of South American Earth Sciences, 4:201-214.

Jost, H.; Figueiredo, A.M.G. \& Ferreira, A.V. 1996a. Are ali detrital metasedimentary rocks of the Crixás Greenstone Belts archean and of the same provenance? A discussion based on REE geochemistry: Symposium Archean of the South American Platform, I, Brasília, Extended Abstracts, p. 44-46.

Jost, H.; Kuyumjian, R. M.; Freitas, A.L.S.; Costa, A.L.L.; Nascimento, C.T.C,; Vasconcelos, F.M.; Galotti, L.; Martins, M.C.A.; Carvalho, M.N. \& Conde, V.C. 1995. Geologia da porção norte do Greenstone Belt de Guarinos, GO. Revista Brasileira de Geociências, 25:51-60.

Jost, H.; Theodoro, S.M.C.H.; Figueiredo, A.M.G.; Boaventura, G.R. 1996 b. Propriedades geoquímicas e proveniência de rochas metassedimentares detríticas arqueanas dos greenstone belts de Crixás e Guarinos, Goiás. Revista Brasileira de Geociências, 26(3): 151-166.

Jost, H.; Vargas, M.C.; Gugelmin, V.; Oliveira, S.R.M. 1989. Sequência Morro Escuro: uma nova unidade estratigráfica do Arqueano/Proterozóico Inferior na região de Crixás, Estado de Goiás. Revista Brasileira de Geociências, 19:283-289. 
Jost, H.; Resende, M.G.; Osborne, G.A.; Queiroz, C.L.; Blum, M.L.B.; Pires, A.C.B.; Moraes, R.A.V. 1998. O Arqueano do Estado de Goiás. In: Haasui, Y. \& Sena Costa, J.B. (edit.) . Geotectônica do Brasil, (submitted)

Kuyumjian, R.M. 1998. Mafic dike swarms of the Goiás Massif, Central Brazil. Revista Brasileira de Geociências, 28(1) (submitted for publication).

Lacerda, H and Lima Júnior, E.A. 1996. Mapa geológico do greenstone belt de Crixás - Faixas Guarinos e Pilar de Goiás. MME/DNPM, $6^{\circ}$ Distrito, Goiânia (unpublished).

METAGO .1985. Projeto Goiás-Mossâmedes, Frente Cubatão. Relatório Final de Pesquisa, DNPM 860.001-002-003-004-005-006/79. (unpublished).

Nilson, A.A.; Botelho, N.F. \& Ferreira Filho, C.F. 1994. Rifteamento crustal Meso-Proterozóico no centro-norte de Goiás. SBG, Congresso Brasileiro de Geologia, 38, Balneário Camboriú, Resumos Expandidos, p.: $258-259$

Oliveira, A.M. \& Barreto, M.A.S. 1988. Geologia da região de Faina (GO), Area III. Unpublished Graduation Report, Universidade de Brasília. $127 \mathrm{p}$.

Pimentel, M.M., Fuck, R.A. and DePRey Silva, L.J.H. 1996. Dados Rb-Sre Sm-Nd da Região de Jussara-Goiás-Mossamedes (GO), e o limite entre terrenos antigos do Maciço de Goiás e o Arco Magmático de Goiás. Revista Brasileira de Geociências, 26:61-70.

Potrel, A.; Resende, M.G. \& Jost, H. 1998. transition in acid magmatism during Archaean: example of the granito-gneiss basement of the Goiás Massif. SBG, Congresso Brasileiro de Geologia, Belo Horíaonte, Extended Abstract Volume, (submitted)

Profumo, J.J.L. 1993. Alteração hidrotermal das rochas ultramáficas e máficas do greenstone belt de Goiás Velho, GO. Unpublished Masters Thesis, Universidade de Brasília, 143 pg.

Resende, M.G. 1994. Geoquímica e petrologia da Formação Aimbé, Grupo Guarinos, Goiás. Unpublished masters Thesis, Universidade de Brasília, $129 \mathrm{p}$

Resende, L. 1995. Estratigrafia, petrografia e geoquímica da sequência sedimentar do greenstone belt de Pilar de Goiás, GO. Unpublished Masters Thesis, Universidade de Brasília, $124 \mathrm{p}$.

Resende, M.G. 1998. Fundamentos para o estudo da evolução das supracrustais metassedimentres da região de Goiás e Faina, Goiás. Unpublished Ph.D. Thesis, Universidade de Brasília.

Resende, M.G. \& Jost, H. 1994. Redefinição da Formação Aimbé, greenstone belt de Guarinos, Goiás e sua interpretação paleogeográfica e paleotectônica. SBG, Núcleo Centro-Oeste, Boletim Informativo $17: 49-57$
Resende, M.G. \& Jost, H. 1997. Aspectos sobre a evolução tectônica das rochas metassedimentares arqueanas da região de Goiás, Goiás. In: Simpósio Nacional de Estudos Tectônicos, VI, Brasília, Resumos Expandidos, $p$. 162-165

Rodrigues, C.V.M. \& Santos Neto, C.J. 1988. Geologia da região de Faina (GO), Área I. Unpublished Graduation Report, Universidade de Brasília. $142 \mathrm{p}$.

Rosa, C.T.A. \& Machado Filho, M.R. 1988. Geologia da região de Faina (GO), A rea $V$. Unpublished Graduation Report, Universidade de Brasília. $160 \mathrm{p}$.

Scartezini, A.A. \& Carvalho, J.B. 1988. Geologia da região de Faina (GO), Área VI. Unpublished Graduation Report, Universidade de Brasília. $132 \mathrm{p}$.

Tassinari, C.C.G.; Siga Jr. O \& Teixeira, W. 1981. Panorama geocronológico do centro-oeste brasileiro: Solução, problemática sugestões: Simpósio de Geologia do Centro-Oeste,1. Anais..., p. 93-114

Teixeira, A.S. 1981. Geologia da região de Goiás-Faina: Simpósio de Geologia Centro-Oeste, Anais..., Goiânia, p. 344-360.

Theodoro, S.C. 1995. Ambiente de Sedimentação da Formação Ribeirão das Antas, Grupo Crixás, Goiás. Unpublished Masters Thesis, Universidade de Brasília, $88 \mathrm{p}$.

Tomazzoli, E.R. 1985. Geologia, Petrologia, deformação e potencial aurifero do greenstone belt de Goiás - GO. Unpublished Masters Thesis, Universidade de Brasilia, 206p.

Tomazzoli, E.R. 1992. A Faixa cidade de Goiás(GO): geocronologia. SBG, Congresso Brasileiro Geologia, São Paulo, Anais...., v.2, p. 178-179.

Tomazzoli, E.R. 1997. Aspectos geológicos e petrológicos do enxame de diques Morro Agudo de Goiás. Unpublished Ph.D. Thesis, Universidade de Brasília, $285 \mathrm{p}$.

Tomazzoli, E.R. \& Nilson, A.A. 1986. Contribuição à geologia, metamorfismo e deformação do Greenstone Belt de Goiás, GO: Congresso Brasileiro Geologia, 34, Goiânia, Anais...., v.2 p.615-629.

Vieira, A.M. \& Duarte, K.S. 1988. Geologia da região de Faina (GO), Área $U$. Unpublished Graduation Report, Universidade de Brasília. $138 \mathrm{p}$.

Winge, M. 1995. Evolução dos Terrenos Granuliticos da Província Estrutural Tocantins, Brasil Central. Unpublished Ph.D. Thesis, Universidade de Brasília, 226 p.

Manuscrito A-950

Submetido em 22 de dezembro de 1997 Revisão dos autores em 20 de junho de 1998 Revisão aceita em 28 de junho de 1998 